\title{
Long-term trends of black carbon and sulphate aerosol in the Arctic: changes in atmospheric transport and source region emissions
}

\author{
D. Hirdman ${ }^{1}$, J. F. Burkhart ${ }^{1}$, H. Sodemann ${ }^{1}$, S. Eckhardt ${ }^{1}$, A. Jefferson ${ }^{2,3}$, P. K. Quinn ${ }^{4}$, S. Sharma ${ }^{5}$, J. Ström ${ }^{6}$, and \\ A. Stohl ${ }^{1}$ \\ ${ }^{1}$ Norwegian Institute for Air Research (NILU), Norway \\ ${ }^{2}$ National Oceanic \& Atmospheric Administration (NOAA) Earth System Research Laboratory (ESRL) Global Monitoring \\ Division, USA \\ ${ }^{3}$ Cooperative Institute for Research in Environmental Sciences, University of Colorado, USA \\ ${ }^{4}$ National Oceanic \& Atmospheric Administration (NOAA) Pacific Marine Environmental Lab (PMEL), USA \\ ${ }^{5}$ Environment Canada, Science and Technology Branch, Climate Research Division, Canada \\ ${ }^{6}$ Norwegian Polar Institute, Troms $\varnothing$, Norway
}

Received: 21 April 2010 - Published in Atmos. Chem. Phys. Discuss.: 10 May 2010

Revised: 1 September 2010 - Accepted: 24 September 2010 - Published: 5 October 2010

\begin{abstract}
As a part of the IPY project POLARCAT (Polar Study using Aircraft, Remote Sensing, Surface Measurements and Models, of Climate, Chemistry, Aerosols and Transport) and building on previous work (Hirdman et al., 2010), this paper studies the long-term trends of both atmospheric transport as well as equivalent black carbon (EBC) and sulphate for the three Arctic stations Alert, Barrow and Zeppelin. We find a general downward trend in the measured EBC concentrations at all three stations, with a decrease of $-2.1 \pm 0.4 \mathrm{ng} \mathrm{m}^{-3} \mathrm{yr}^{-1}$ (for the years 1989-2008) and $-1.4 \pm 0.8 \mathrm{ng} \mathrm{m}^{-3} \mathrm{yr}^{-1}$ (2002-2009) at Alert and Zeppelin respectively. The decrease at Barrow is, however, not statistically significant. The measured sulphate concentrations show a decreasing trend at Alert and Zeppelin of $-15 \pm 3 \mathrm{ng} \mathrm{m}^{-3} \mathrm{yr}^{-1}$ (1985-2006) and $-1.3 \pm 1.2 \mathrm{ng} \mathrm{m}^{-3} \mathrm{yr}^{-1}$ (1990-2008) respectively, while there is no trend detectable at Barrow.

To reveal the contribution of different source regions on these trends, we used a cluster analysis of the output of the Lagrangian particle dispersion model FLEXPART run backward in time from the measurement stations. We have investigated to what extent variations in the atmospheric circula-
\end{abstract}

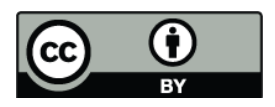

Correspondence to: D. Hirdman (dhi@nilu.no) tion, expressed as variations in the frequencies of the transport from four source regions with different emission rates, can explain the long-term trends in EBC and sulphate measured at these stations. We find that the long-term trend in the atmospheric circulation can only explain a minor fraction of the overall downward trend seen in the measurements of EBC $(0.3-7.2 \%)$ and sulphate $(0.3-5.3 \%)$ at the Arctic stations. The changes in emissions are dominant in explaining the trends. We find that the highest EBC and sulphate concentrations are associated with transport from Northern Eurasia and decreasing emissions in this region drive the downward trends. Northern Eurasia (cluster: NE, WNE and ENE) is the dominant emission source at all Arctic stations for both EBC and sulphate during most seasons. In wintertime, there are indications that the EBC emissions from the eastern parts of Northern Eurasia (ENE cluster) have increased over the last decade.

\section{Introduction}

Short-lived pollutants have recently received much attention as climate forcers, particularly in the Arctic (Quinn et al., 2008). Black carbon (BC) has gained the greatest interest due to its strong effects on the radiative balance in the Arctic, both as an Arctic haze aerosol absorbing short-wave

Published by Copernicus Publications on behalf of the European Geosciences Union. 
radiation in the atmosphere (Polissar et al., 1999) as well as by decreasing the albedo if deposited on ice or snow (Hansen and Nazarenko, 2004; Flanner and Zender, 2006; Flanner et al., 2007). Like other aerosols, BC may also influence the microphysical properties of clouds (Garrett et al., 2002; Bréon et al., 2002). To fully understand past and present effects of $\mathrm{BC}$ on the Arctic climate, it is necessary to know the long-term changes of $\mathrm{BC}$ concentrations. Furthermore, it is important to know where the source regions of $\mathrm{BC}$ are located and how their contributions to $\mathrm{BC}$ in the Arctic have changed over time. A recent ice-core study by McConnell et al. (2007) presented a historical BC record, which showed that $\mathrm{BC}$ concentrations over the ice cap of Greenland peaked around 1910 and thereafter decreased steadily. Continuous measurements of aerosol light absorption (which can be converted to equivalent $\mathrm{BC}$ (EBC) concentrations) at Alert and Barrow started in the late 1980s (see Table 1). These records are now long enough for meaningful trend analysis. Previous studies using these data sets have shown - in agreement with the ice-core study of McConnell et al. (2007) - a general decrease of EBC since the start of the measurements (Sharma et al., 2004, 2006; Quinn et al., 2007). However, small increases of EBC were reported for both stations for the last years of each study (Sharma et al., 2006; Quinn et al., 2007). The two parallel EBC measurement time series available from Zeppelin (Table 1) are both still relatively short but for one a decreasing trend over the last decade was reported (Eleftheriadis et al., 2009).

The major BC source region for the Arctic surface stations has repeatedly been identified as Northern Eurasia (Polissar et al., 2001; Sharma et al., 2004, 2006; Stohl, 2006; Eleftheriadis et al., 2009; Hirdman et al., 2010), at least in winter and spring. In the past, these sources have been assumed to be anthropogenic but several recent case studies show that agricultural as well as boreal forest fires in central and western Eurasia may in fact, for periods of time, dominate the aerosol concentrations in large parts of the Arctic troposphere in spring (Stohl et al., 2007; Treffeisen et al., 2007; Engvall et al., 2009; Warneke et al., 2009, 2010). The BC source locations in summer are still debated. Neither Polissar et al. (2001) nor Sharma et al. (2006) found any specific source regions for Alert in summer while the later study identified Western China and the Pacific to be associated with enhanced EBC concentrations at Barrow. Iziomon et al. (2006) on the other hand pointed out that Barrow in summer was influenced by emissions from anthropogenic sources as well as from forest fires originating in the central and eastern parts of Russia. The studies of EBC measured at Zeppelin agree in that the continental influence on the station is limited during summertime but the results are inconclusive with regard to specific source regions (Eleftheriadis et al., 2009; Hirdman et al., 2010). Eleftheriadis et al. (2009) pointed out the countries around the Baltic Sea as potential source regions together with Scotland/Ireland and regions in Russia (NorthWest corner and Norilsk). Other studies have emphasized the importance of emissions from yearly reoccurring boreal forest fires at high latitudes to the EBC concentrations not only at Zeppelin but for the whole Arctic troposphere in summer (Stohl, 2006; Stohl et al., 2006; Hirdman et al., 2010). Model results indicate that source regions for $\mathrm{BC}$ in the middle and upper troposphere are markedly different, with a stronger influence from source regions further south (Koch and Hansen, 2005; Stohl, 2006; Hirdman et al., 2010).

Several studies have attempted to estimate to what extent the observed trends in the Arctic EBC concentrations can be attributed to changes in atmospheric transport compared to the emission changes in the source regions. A study by Sharma et al. (2004) concluded that the trends in EBC seen at Alert are mainly due to changed emissions in Russia while a later study pointed out the importance of the interaction between atmospheric transport and variable emissions to explain the trends in EBC concentrations seen at Alert and Barrow (Sharma et al., 2006). However, a recent study by Gong et al. (2010) concluded that the trends in EBC and sulphate seen at Alert were strongly correlated to the anthropogenic emissions of Northern Eurasia and North America and consistent with their documented reductions.

Most aerosols predominantly scatter rather than absorb light (Charlson et al., 1992). Even though the trend of aerosol light scattering is not studied here specifically, it is still of interest to know how its tendency correlates to the EBC trends. Measurements of the aerosol light scattering coefficient at Barrow have been made since May of 1976. Bodhaine and Dutton (1993) reported that the spring-time values were stable for the first three years, and then experienced two years of lower values before they reached a maximum in 1982 and decreased strongly thereafter until 1992. From 1997 until 2006, the data show a significant increase in March but no trend at all later in spring (Quinn et al., 2007). Thus, both EBC and aerosol light scattering show a strong decrease during the 1980s and until the late 1990s' but a slight increase or no trend since then. One important light scattering component of the Arctic aerosol is sulphate, for which in situ measurements are available as far back as the late 1970s. Sirois and Barrie (1999) and Sharma et al. (2004) reported that there was no trend in the measured sulphate concentrations at Alert between 1980 and 1991, but they observed a significant decrease of up to $56 \%$ thereafter which was speculated to reflect the reduced emissions from Russia. This negative trend was confirmed at several stations around the Arctic (Quinn et al., 2007), and Quinn et al. (2009) reported a $60 \%$ decrease over the past three decades.

In a previous paper we investigated the current sources and sinks of several short-lived species for four Arctic stations (Hirdman et al., 2010). For our statistical analysis, we combined the measurement data with transport model calculations. We took advantage of the superior performance of the model calculations of a Lagrangian particle dispersion model (LPDM) compared with trajectory calculations which ignore atmospheric turbulence and convection (Stohl et al., 
Table 1. Measurement data used in this study. Further information on the instrumentation and data can be found in the listed references.

\begin{tabular}{|c|c|c|c|c|c|c|}
\hline Station & Lat/Lon & Species & Time period & Time resolution & Data availability & References \\
\hline \multirow[t]{2}{*}{ Alert } & \multirow[t]{2}{*}{$62,3^{\circ} \mathrm{W} 82,5^{\circ} \mathrm{N}$} & $\mathrm{EBC}$ & 1989-2008 & $1 \mathrm{~h}$ & $75.7 \%$ & Sharma et al. $(2004,2006)$ \\
\hline & & NSS sulphate & 1985-2006 & 3-9 days & $98.2 \%$ & Sirois and Barrie (1999) \\
\hline \multirow[t]{2}{*}{ Barrow } & \multirow[t]{2}{*}{$156,6^{\circ} \mathrm{W} 71,3^{\circ} \mathrm{N}$} & $\mathrm{EBC}$ & 1988-2008 & $1 \mathrm{~h}$ & $58.8 \%$ & Sharma et al. (2006) \\
\hline & & NSS sulphate & 1997-2008 & $1-5$ days & $61.1 \%$ & Quinn et al. (1998) \\
\hline \multirow[t]{2}{*}{ Zeppelin } & \multirow[t]{2}{*}{$11,9^{\circ}$ E $78,9^{\circ} \mathrm{N}$} & $\mathrm{EBC}$ & 2002-2009 & $1 \mathrm{~h}$ & $83.6 \%$ & Krecl et al. (2007) \\
\hline & & Total sulphate & 1990-2008 & $24 \mathrm{~h}$ & $94.7 \%$ & Aas et al. (2008) \\
\hline
\end{tabular}

2002; Han et al., 2005). Here we extend the work of Hirdman et al. (2010) by applying the LPDM for the entire time period for which Arctic measurements of EBC and sulphate are available.

We present climatologies of atmospheric transport from the mid-latitudes to the three Arctic observatories Alert (Canada), Barrow (Alaska), and Zeppelin (Svalbard, Norway) and assess the relative importance of changing transport patterns and changing source region emissions on measured concentrations of EBC and sulphate. The paper is structured as follows: in Sect. 2, the methods used are described. Subsequently, in Sect. 3.1, the climatologies of atmospheric transport towards the three Arctic observatories are presented. In Sect. 3.2, the potential source regions of the clustered transport are identified and thereafter characterized for trends. In the following Sects. 3.3 and 3.4, the EBC and sulphate mean concentrations are investigated in association to the different clusters. Section 3.5 separates the influence of changing transport patterns from the changes in clustered source region emissions and quantifies the contribution of each on the overall trend. Thereafter follows a discussion of the implications of the results. Conclusions will be drawn in Sect. 4 .

\section{Methods}

\subsection{Measurements}

\subsubsection{Sites}

The measurement data used in this study have been collected at three different sites: Alert, Canada $\left(62.3^{\circ} \mathrm{W}\right.$, $82.5^{\circ} \mathrm{N}, 210 \mathrm{~m}$ a.s.l. $)$, Barrow, Alaska $\left(156.6^{\circ} \mathrm{W}, 71.3^{\circ} \mathrm{N}\right.$, $11 \mathrm{~m}$ a.s.l.) and Zeppelin on Svalbard, Norway $\left(11.9^{\circ} \mathrm{E}\right.$, $78.9^{\circ} \mathrm{N}, 478 \mathrm{~m}$ a.s.1.). The Alert station is located on the north-eastern tip of Ellesmere Island (Hopper et al., 1994; Helmig et al., 2007a). The surroundings, both land and ocean, are mainly ice or snow covered 10 months of the year. The Barrow station lies $8 \mathrm{~km}$ northeast from a small settlement, and it is surrounded by the Arctic Ocean except for the south where there is Arctic tundra (Helmig et al., 2007a, b). It is therefore influenced by both maritime and continental air. The Zeppelin station is situated on a mountain ridge on the western coast of Spitsbergen, Svalbard. Contamination from the small nearby community of Ny Ålesund located at the coast is minimal, due to the usually stable stratification of the atmosphere and the location of the station $400 \mathrm{~m}$ above the community. Air masses can arrive either from the icefree North Atlantic Ocean or from the generally ice-covered Arctic Ocean.

\subsubsection{Data}

Table 1 summarizes the measurement data used here. The EBC data derived from aerosol light absorption measurements from all three stations have a time resolution of $1 \mathrm{~h}$. Data were averaged to match the model time resolution of $3 \mathrm{~h}$ (see Sect. 2.2). For the daily sulphate measurements from Zeppelin, the 3-hourly model results were averaged to daily values. The sample duration of sulphate measurements at Alert and Barrow varied and was, therefore put on a common daily mean basis together with the model data.

Aerosol light absorption measurements with aethalometers have been made at Barrow since 1988 and at Alert since 1989. In October 1997, as a part of the standard NOAA/ESRL/GMD aerosol optical measurements system design (Delene and Ogren, 2002), the aerosol instrumentation at Barrow was upgraded and since then a particle soot absorption photometer (PSAP) has been used to measure the light absorption. At Zeppelin, the measurements which are analyzed and presented in this study have been performed since 2002 using a custom built PSAP that is based on the same measurement principle. The BC study by Eleftheriadis et al. (2009) used data from an aethalometer running in parallel with the PSAP. The responses of both aethalometers and PSAPs depend on the loading of particles on the filter and on the amount of light that the particles scatter (Bond et al., 1999; Weingartner et al., 2003; Arnott et al., 2005). No corrections for this have been made for the aethalometer measurements, neither at Alert nor at Barrow. However, the PSAP data taken at Barrow and Zeppelin were corrected for these dependencies according to the procedure described by Bond et al. (1999). The aethalometer output is reported directly as $\mathrm{BC}$ concentrations through an internal conversion using an assumed mass absorption efficiency. The PSAP 
measurements are reported as the particle light absorption coefficient $\sigma_{\text {ap }}$. Conversion between $\sigma_{\text {ap }}$ and BC is not straightforward and requires the assumption that all the light absorption measured is from BC. It is also assumed that all BC has the same light absorption efficiency. The PSAP data will therefore be reported as EBC, where $\sigma_{\text {ap }}$ values have been converted approximately to $\mathrm{BC}$ mass concentration using a value of $10 \mathrm{~m}^{2} \mathrm{~g}^{-1}$, typical of aged $\mathrm{BC}$ aerosol (Bond and Bergstrom, 2006). The conversion to $\mathrm{BC}$ in the aethalometers is done internally but relies on the same assumptions. Therefore, we will also refer to the aethalometer data as EBC. At Alert, the EBC data were further corrected based on a comparison with elemental carbon measurements based on a thermal method (Sharma et al., 2004).

An inter-comparison between the aethalometer and PSAP measurements at Barrow was made for a period of overlapping measurements during 1998. The results indicated that the calculated mean and median values of the aethalometer measurements were, $19.9 \%$ and $19.5 \%$, respectively, higher than the PSAP measurements (e.g. see Fig. 16). Unfortunately, the differences in the datasets are not systematic. Thus, it may be misleading to join the two time series and we will report trends separately for the aethalometer and PSAP measurements at Barrow.

To avoid local contamination by emissions from the town of Barrow, EBC values at Barrow were only used when the wind direction fell within the "clean-air sector" from $0-130^{\circ}$ (Bodhaine, 1995). This screening effectively excludes direct transport from most North American source regions. Thus, the statistical analysis of North American source regions of $\mathrm{BC}$ for Barrow relies on indirect transport events, which are likely associated with larger errors in the simulated transport. In addition, signals of BC from source regions both in North America and on other continents are likely often mixed during such indirect transport events, which make a clear identification of source regions in North America more difficult.

Measurements of sulphate and other inorganic ions at Alert, Barrow and Zeppelin were analyzed using ion chromatographic analyses on filter samples taken at daily or longer intervals (Table 1). The stations sample different particle size ranges. At Zeppelin, particles smaller than about $10 \mu \mathrm{m}$ are collected, at Alert, the total suspended particulates (TSP) are sampled; and at Barrow, sub- and super-micron particles are collected separately but in this study only the submicron measurements are used. Measured sulphate concentrations at Alert and Barrow were corrected for the influence from sea-salt by using measurements of sodium on the same filters and a ratio of sulphate to sodium in seawater. At Zeppelin, the sodium content in the filters has only been measured since 1999. In order to use all the data since 1990, the sulphate measurements at Zeppelin were not corrected for the influence of sea-salt sulphate. Due to the high altitude location of the Zeppelin station, the sea salt contribution is only $16-22 \mathrm{ng} / \mathrm{m}^{3}$ or $9-18 \%$ of the measured annual mean concentrations since 1999 .
For interpretation of our results, we also used various indices for atmospheric circulation patterns. Daily North Atlantic Oscillation (NAO) index data used were provided by the Climate Analysis Section, NCAR, Boulder, USA, (Hurrell 1995). The seasonal values of the atmospheric circulation indices NAO, Pacific-North American pattern (PNA) and Arctic Oscillation (here abbreviated as AOI in order not to confuse it with a later defined transport cluster), used in this study were derived from monthly values provided by the Climate Prediction Center (CPC) at the National Weather Service (NWS), USA. The monthly NAO and PNA index values were derived using principal component analysis (Barnston and Livezey, 1987), while the AOI index was derived using empirical orthogonal functions (EOF) (Higgins et al., 2000).

\subsection{Model calculations}

In our trend analyses we make use of the FLEXPART LPDM (Stohl et al., 1998, 2005; Forster et al., 2007). FLEXPART calculates the trajectories of so-called tracer particles using the mean winds interpolated from the analysis fields plus parameterizations representing turbulence and convective transport. These processes, which are not included in standard trajectory models, are important for a realistic simulation of the transport of trace substances (Stohl et al., 2002). As shown in Han et al. (2005) and discussed in Hirdman et al. (2010), this leads to more accurate results even though the calculations become more computationally demanding and the statistical analysis of the model results more challenging.

FLEXPART was run backward in time using operational analyses from the European Centre for Medium-Range Weather Forecasts (ECMWF, 2002) with $1^{\circ} \times 1^{\circ}$ resolution for the period 2002-2008. For earlier years, the ERA-40 reanalysis data (Uppala et al., 2005) were used also with $1^{\circ} \times 1^{\circ}$ resolution. Analyses at 00:00, 06:00, 12:00 and 18:00 UTC and 3-hour forecasts at 03:00, 09:00, 15:00 and 21:00 UTC were used. During every 3-h interval, 40000 particles were released at the measurement point and followed backward for 20 days. The reported global mean atmospheric lifetimes of $\mathrm{BC}$ range widely in different studies, from 3-4 days (Liu et al., 2005) to 4-8 days (Park et al., 2005). In the Arctic, the lifetimes may be as long as several weeks to a month during winter (Sharma et al., 2006). The 20 days of our transport simulations should therefore be long enough to capture transport from the most relevant source regions.

In backward mode, FLEXPART calculates an emission sensitivity function $S$, called source-receptor-relationship by Seibert and Frank (2004). The $S$ value (in units of $\mathrm{s} \mathrm{m}^{-3}$ ) in a particular grid cell is proportional to the particle residence time in that cell and measures the simulated concentration at the receptor that a source of unit strength $\left(1 \mathrm{~kg} \mathrm{~s}^{-1}\right)$ in the cell would produce for an inert tracer which is not affected by chemical or other removal processes. The distribution of $S$ close to the surface is of particular interest, as most emissions 
occur near the ground. Thus, $S$ values are calculated for a so-called footprint layer $0-100 \mathrm{~m}$ above ground. $S$ can be folded with emission distributions of any species to calculate receptor concentrations of that species ignoring loss processes. However, here concentrations are not calculated but instead $S$ is used directly for our statistical analyses.

\subsection{Statistical methods}

We used a cluster analysis (see, e.g., Kalkstein et al., 1987) to semi-objectively classify the emission sensitivities from FLEXPART into distinctly different groups. The classifications, done separately for the three stations, allow studying how the frequency of the different clusters has changed over time and, thus, how atmospheric transport to a station has changed. We also investigate how the measured EBC and sulphate concentrations have changed for every transport cluster. These changes are likely driven by emission changes in the major source regions. However, trends in precipitation or other scavenging processes along the major transport pathways the stations may also influence the trends of the measured species concentrations for particular clusters. Such trends (New et al., 2001; Adam and Lettenmaier, 2008) are not homogeneous across the Arctic and their overall impact on aerosol wet scavenging has not been studied. Furthermore, the trends of acidifying species in Arctic precipitation agree well with reported emission trends (Hole et al., 2009), whereas changes in removal efficiency seem to have a smaller influence on the reported deposition values. In this study we therefore assume that the influence of temporal trends in scavenging processes is not significant allowing us to separate the effects of changes in atmospheric transport to the Arctic from effects of emission changes in a few important source regions, on the Arctic EBC and sulphate concentrations.

In principle, the gridded FLEXPART footprint emission sensitivities $S(i, j, n)$ could have been clustered directly. Here, $i$ and $j$ are the indices of the latitude/longitude grid and $n$ runs over the total number of cases $N$, where each case resembles a model calculation linked with a corresponding measurement and where both are averaged over the same time interval. However, due to the large number of grid cells, this is not feasible. Instead, following the approach used by Paris et al. (2010), we divided the Earth into 9 different geographical regions (Fig. 1). We then sum $S(i, j, n)$ within each of these 9 regions and use these 9 values, subsequently called $S_{T}(l, n)$ for the clustering. Here, $l$ runs over the 9 geographical regions and replaces the grid indices $i$ and $j$. To avoid that relatively small changes in transport over regions close to the station have a too large influence on the clustering result, $S_{T}$ was standardized (Eq. 1):

$$
S_{\mathrm{ST}}(l, n)=\frac{S_{T}(l, n)-\overline{S_{T}(l)}}{\sigma(l)}
$$

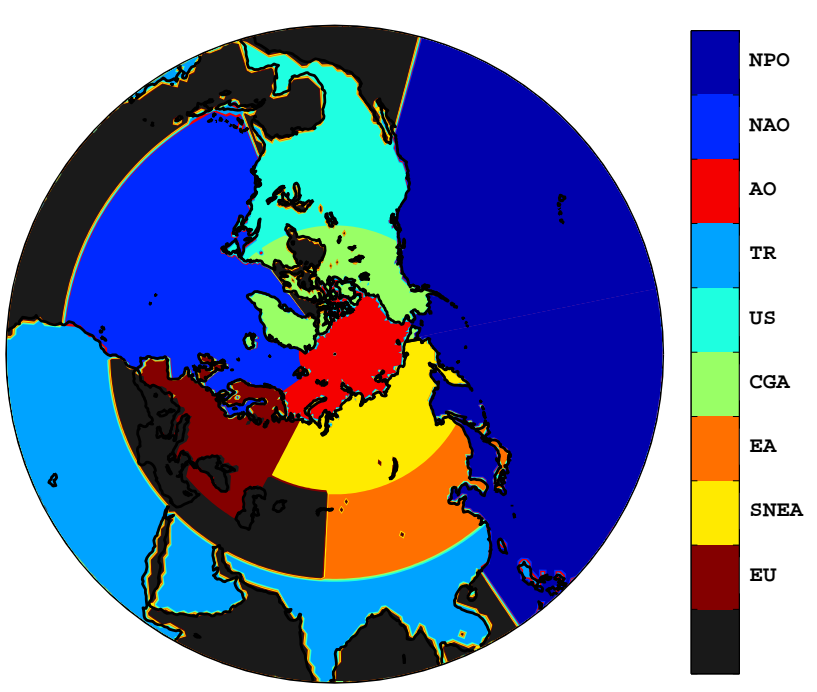

Fig. 1. Geographical regions used for the clustering of the footprint emission sensitivities. NPO, NAO and AO represent the North Pacific Ocean, North Atlantic Ocean and Arctic Ocean respectively. TR represents the land masses in the tropics and southern hemisphere. US is USA (except Alaska and Hawaii) and Central America. CGA stands for Canada, Greenland and Alaska. EA, SNEA and EU represent Eastern Asia, Siberia and North-East Asia and Europe respectively.

where $\overline{S_{T}(l)}$ and $\sigma(l)$ are the mean value and standard deviation of $S_{T}$ within each region.

$S_{\mathrm{ST}}$ was then used to identify $M$ different transport clusters. The clustering was done using a two-phase iterative algorithm that minimizes the point-to-centroid distances summed over all $M$ clusters, where each of the values in $S_{\mathrm{ST}}$ was treated as a point in parameter space. In the first phase, the $S_{\mathrm{ST}}$ values are simultaneously reassigned to their nearest cluster centroid until convergence of cluster membership is achieved. The result from the first phase serves as an approximate solution and starting point for the second phase. In the second phase, each $S_{\mathrm{ST}}$ value is individually reassigned if this reduces the sum of distances. After each reassignment the cluster centroids are recalculated in order to find a local and hopefully a global minimum of the sum of all point-tocentroid distances (Seber, 1984; Spath, 1985).

The number of clusters chosen for further analysis is always subjective (Kalkstein et al., 1987). Here, it is a compromise between a desired large number of clusters to clearly separate differences in major transport patterns and the necessity to have a large enough number of cases in each cluster, so that seasonal averages over these cases are suitable for trend analyses. We successively varied the number of clusters $(M=2, . ., 8)$. Using visual analysis and applying the silhouette technique (Kaufman and Rousseeuw, 1990) we chose to use $M=4$ clusters for all three stations. The silhouette technique was applied here to further establish the findings from the visual analysis by measuring how closely the 
data within each cluster match one another and how loosely they match the data of the neighbouring clusters. Since the first centroids are chosen in a random way, the clustering was repeated several times and the most persistent patterns were selected for further analysis.

For displaying our results, we first calculate the mean footprint sensitivity $S_{\mathrm{MF}}$ :

$S_{\mathrm{MF}}(i, j)=\frac{1}{N} \sum_{n=1}^{N} S(i, j, n)$

$S_{\mathrm{MF}}$ indicates where, on a climatological basis, surface sources can potentially influence the measurements during the last 20 days of transport. Similarly, we calculate the mean footprint emission sensitivity for each individual cluster $m$ :

$S_{\mathrm{CM}}(i, j, m)=\frac{1}{N_{m}} \sum_{n=1}^{N_{m}} S(i, j, n)$

Here $n$ runs over all $N_{m}$ cases in cluster $m$. Finally, for displaying our results, we normalize $S_{\mathrm{CM}}$ with $S_{\mathrm{MF}}$ :

$S_{\mathrm{CF}}(i, j, m)=\frac{1}{M} \frac{S_{\mathrm{CM}}(i, j, m)}{S_{\mathrm{MF}}(i, j)}$

to show, for every cluster, the cluster-mean footprint emission sensitivity relative to the total mean footprint sensitivity. Since we chose $M=4$ clusters, $S_{\mathrm{CF}}(i, j, m)>0.25$ indicates an above-average footprint sensitivity for cluster $m$ in grid cell $(i, j)$. For instance, a value of 1 indicates that influence from that region is four times as strong for cluster $m$ as for the total mean situation. On the other hand $S_{\mathrm{CF}}(i, j, m)<0.25$ indicates a below-average footprint sensitivity in grid cell $(i, j)$ for cluster $m$. This is similar to methods where the grouping is done based on measurement data (Ashbaugh, 1983; Ashbaugh et al. 1985; Hirdman et al. 2009, 2010).

A linear regression approach was applied in order to analyze the overall trends in a) cluster frequencies showing changes in atmospheric transport to the stations, and b) the measured concentrations of the different species at each station. The linear regression used here is part of a statistical toolbox which makes use of a least-squares approach to find a solution to the system, where the norm of the residual vector is minimized (Chatterjee and Hadi, 1986). The confidence intervals are computed using a QR (orthogonal, triangular) decomposition of the predictor variable (Goodall, 1993). In trend figures, trends statistically significantly (at the $90 \%$ level) different from zero are plotted with a solid line, insignificant trends with a dashed line.

\section{Results}

\subsection{Transport climatologies}

As explained by Hirdman et al. (2010), plots of $S_{\mathrm{MF}}$ (Eq. 2) can be interpreted as flow-climatologies where high values indicate frequent transport reaching the station from that region. To highlight overall trends in transport, we initially focus on the years 1990-1994 when most of the measurements discussed in this paper were started, and on the last five years (2004-2008) for which measurements data were available for most data sets. We show difference plots of $S_{\mathrm{MF}}$ for these periods to the mean for the period 1985-2009 (Figs. 2-4).

Alert: for Alert, during winter (DJF), transport from western Russia was enhanced in the earlier period (1990-1994) (Fig. 2a), while transport from the north-eastern parts of Russia, Greenland and Quebec and the neighbouring parts of the Arctic Ocean was more pronounced during the period 20042008 (Fig. 2c). In summer (JJA), the influence from Northern Eurasia and the North Pacific Ocean was more pronounced during the first five years (Fig. 2d), whereas transport from the Arctic Ocean, the north-western North Atlantic Ocean and Greenland was strong during the last five years (Fig. 2f).

Barrow: in the winters of 1990-1994, Barrow saw more atmospheric transport from Kazakhstan, eastern Russia and the East Siberian Sea (Fig. 3a), whereas during the winters of 2004-2008, the station was more influenced by transport from north-western Eurasia, Greenland and the Canadian Arctic (Fig. 3c). In summer, the first period was characterized by enhanced transport from the remote parts of the Arctic Ocean, the North Atlantic Ocean and their coastal regions (Fig. 3d), whereas the later period was more influenced by local transport from the Beaufort Sea (Fig. 3f).

Zeppelin: for Zeppelin, in the winters of 1990-1994, transport from Russia was more frequent (Fig. 4a), while transport from Europe, Greenland and eastern Canada was more frequent during the winters of 2004-2008 (Fig. 4c). In summer, the first period was characterized by enhanced influence from North-Central Eurasia and more remote influences from North Atlantic Ocean and North Pacific Ocean (Fig. 4d), whereas the later period was more influenced by transport from within the Arctic Ocean, Greenland and North-Eastern Canada (Fig. 4f).

These differences are associated with the overall difference in the mean circulation. The early period was characterized by a stronger Icelandic low, with influence extending well across the Eurasian Arctic, and a weaker Siberian high (Fig. 5). The Pacific storm track was also weaker than on average. In the later period, the North Atlantic storm track was somewhat weaker than normal, and the Siberian high more pronounced. This change in the mean circulation may also be identified with the NAO index (Hurrell and Deser, 2010), which was more strongly positive during the winters of 1990-1994 (average PC-based NAO index of 1.28) than during the winters of 2004-2008 (average of 0.51). A pronounced shift from higher to lower NAO index values occurred in the late 1980s and early 1990s (Fig. 6). Related changes can also be seen in the AOI and PNA indices (Fig. 6). Thus, monitoring of EBC started during a period with sustained high values of the NAO index. As shown by Eckhardt 

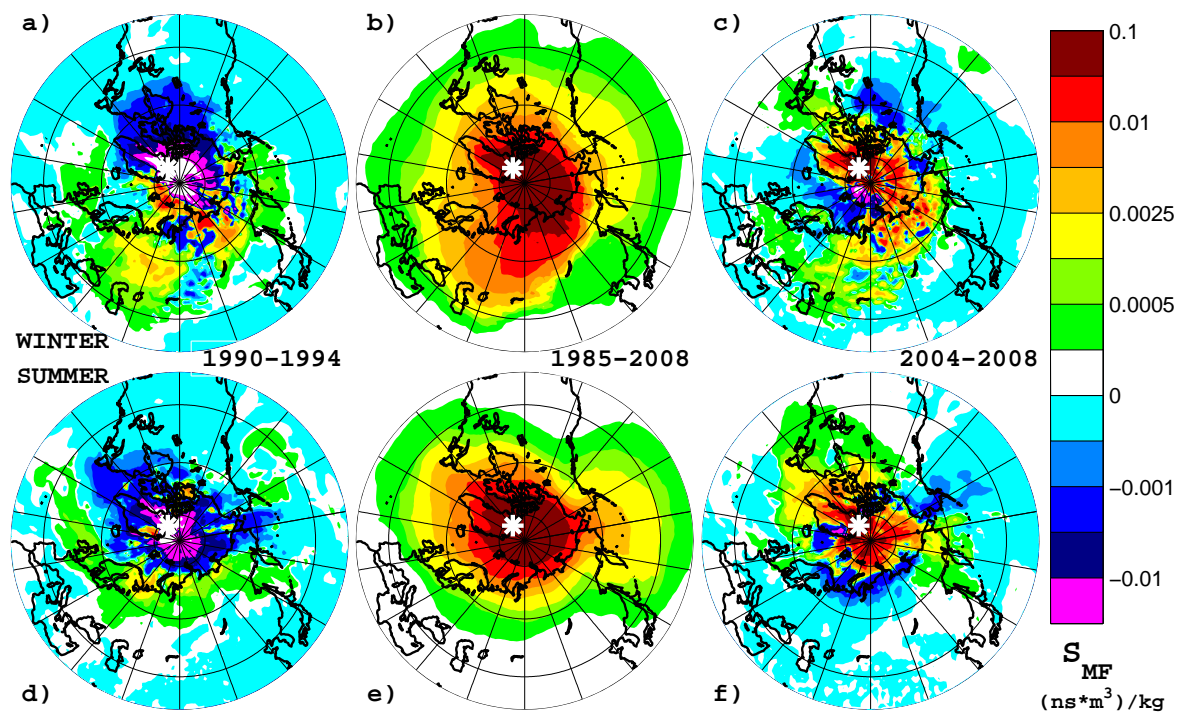

Fig. 2. Transport climatologies $\left(S_{\mathrm{MF}}\right)$ at Alert during winter (upper row of panels) and summer (lower row). The middle column shows the mean $S_{\mathrm{MF}}$, averaged over the whole time period (1985-2008). The left column of panels illustrates the difference from the mean flow for the early period 1990-1994, and the right column illustrates the difference from the mean for the late period 2004-2008. The station's location is marked with a white asterisk.
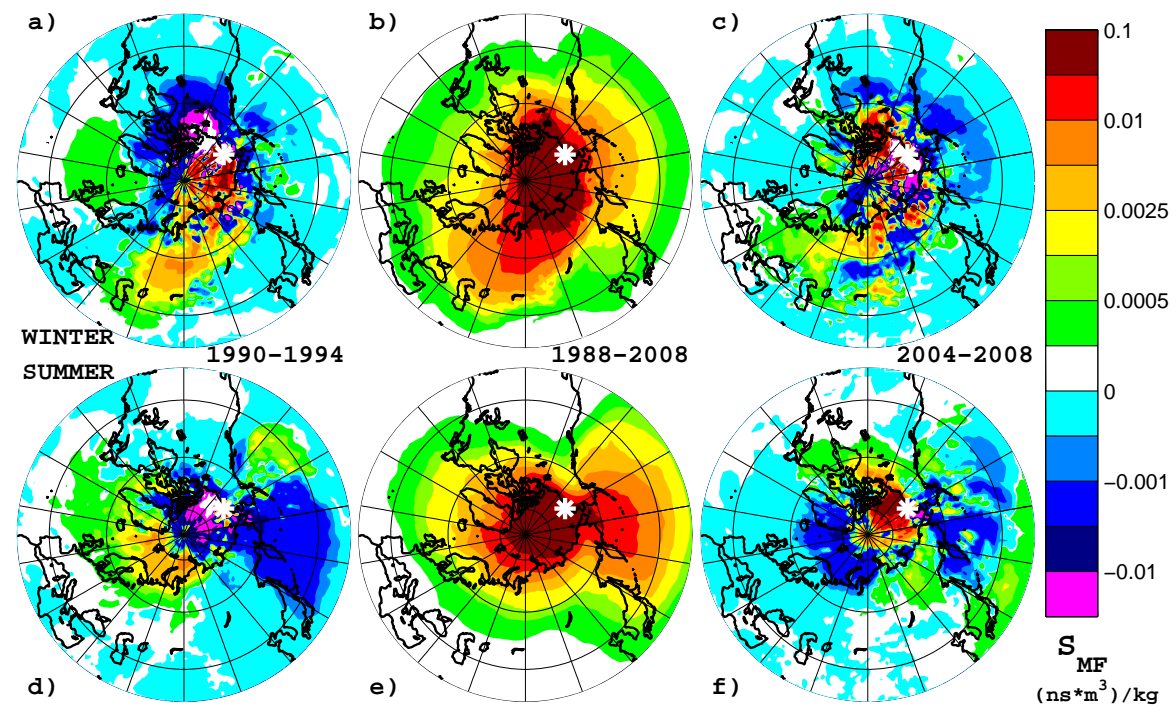

Fig. 3. Transport climatologies $\left(S_{\mathrm{MF}}\right)$ at Barrow during winter (upper row of panels) and summer (lower row). The middle column shows the mean $S_{\mathrm{MF}}$, averaged over the whole time period (1988-2008). The left column of panels illustrates the difference from the mean flow for the early period 1990-1994, and the right column illustrates the difference from the mean for the late period 2004-2008. The station's location is marked with a white asterisk.

et al. (2003), transport from mid-latitude pollution source regions and particularly from Eurasia is enhanced for high phases of the NAO. Burkhart et al. (2006) have also shown positive correlation between NAO and nitrate concentrations in Greenland ice cores. These findings are in agreement with our result of more frequent transport from lower-latitude continental regions during the first five years of the measurements than during the last five years, for all three stations.
The influence of transport from the North Atlantic Ocean on the Arctic weakens with distance but even for Barrow, its influence exceeds that of transport from the North Pacific Ocean (Dickson et al., 2000). This explains the strong correlation of transport with NAO even for Barrow. The fact that similar differences in the atmospheric flow patterns exist for the summers (Figs. 2-4d and f) corroborates well with the picture that the NAO influence is significant also during 

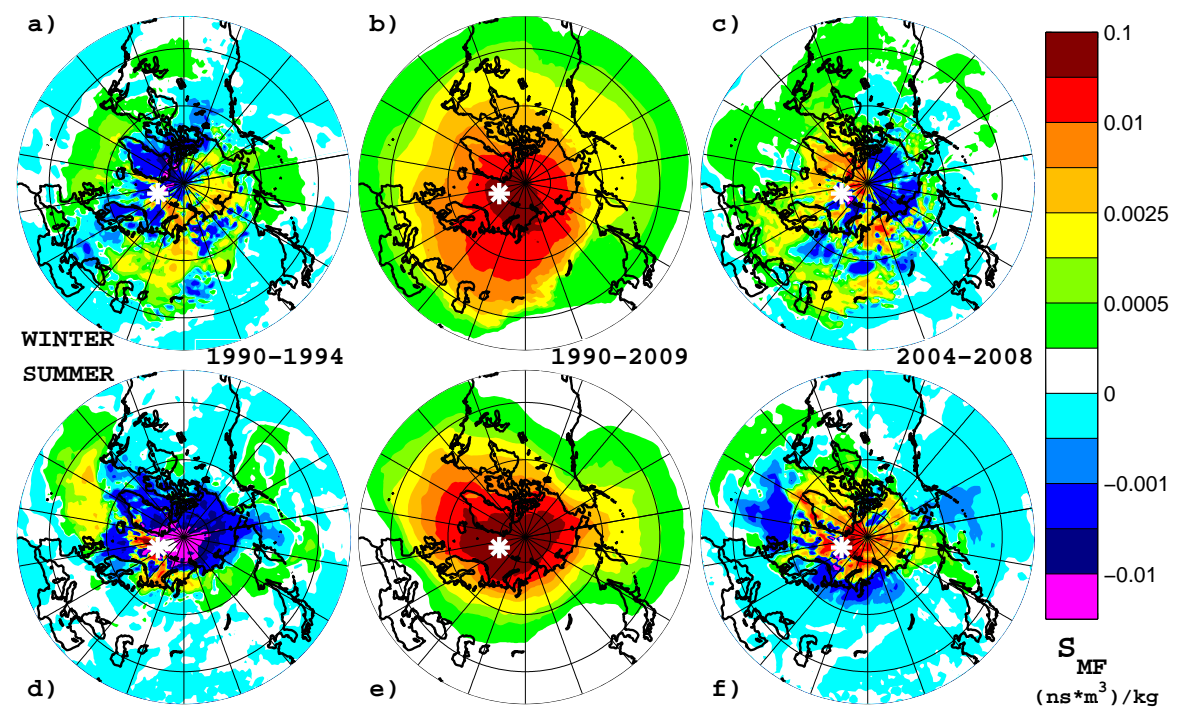

Fig. 4. Transport climatologies $\left(S_{\mathrm{MF}}\right)$ at Zeppelin during winter (upper row of panels) and summer (lower row). The middle column shows the mean $S_{\mathrm{MF}}$, averaged over the whole time period (1990-2009). The left column of panels illustrates the difference from the mean flow for the early period 1990-1994, and the right column illustrates the difference from the mean for the late period 2004-2008. The station's location is marked with a white asterisk.
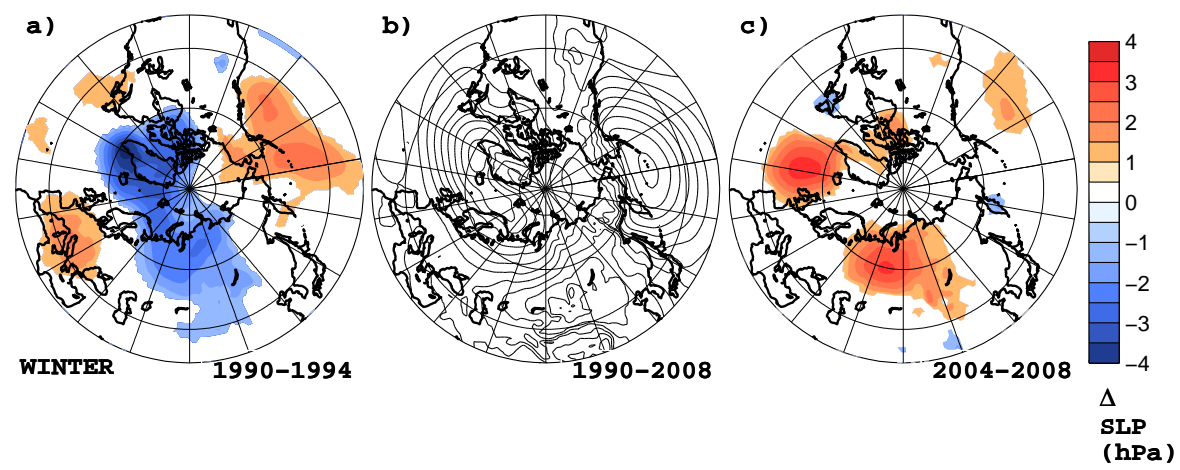

Fig. 5. Mean sea level pressure (SLP) during winter over the Arctic. The middle panel shows the mean SLP with contours at $3 \mathrm{hPa}$ interval (1990-2008). The left and right panels show the mean SLP for the period of interest (1990-1994, left; 2004-2008, right) minus the mean SLP over the entire time period. Blue and red areas display, respectively, lower and higher SLP than averaged over the whole period.

summer (Folland et al., 2009). The use of ERA-40 reanalysis data up until 2001 and operational analyses data thereafter does not seem to have caused any discontinuities in simulated transport.

\subsection{Cluster analysis results: seasonalities of transport}

For each of the three stations one set of four unique clusters was identified by the cluster analysis spanning the entire time period of available measurements (1985-2009). The clusters represent unique transport pathways (see Sect. 2.3). The four unique clusters identified for Barrow and Alert have similar characteristics, therefore we give them the same names for the purposes of discussion. For Zeppelin, only two of the four clusters are similar to clusters found for the other stations; the other two represent unique transport pathways to Zeppelin. Below we describe the six clusters relevant to the three stations.

The 1 st cluster is common for all three stations and features enhanced $S_{\mathrm{CF}}$ values over the Arctic Ocean (and the oceans beyond for Barrow and Zeppelin). It will therefore be referred to as the Arctic Ocean (AO) cluster (panels a in Figs. 7-9). The 2nd cluster is also common for all three stations and will be referred to as North American (NA) cluster since it is associated with high $S_{\mathrm{CF}}$ values over the North American continent and to some extent also over the North Atlantic Ocean (panels b in Figs. 7-9). The 3rd cluster, influencing Alert and Barrow (Figs. 7c and 8c), shows high $S_{\mathrm{CF}}$ 


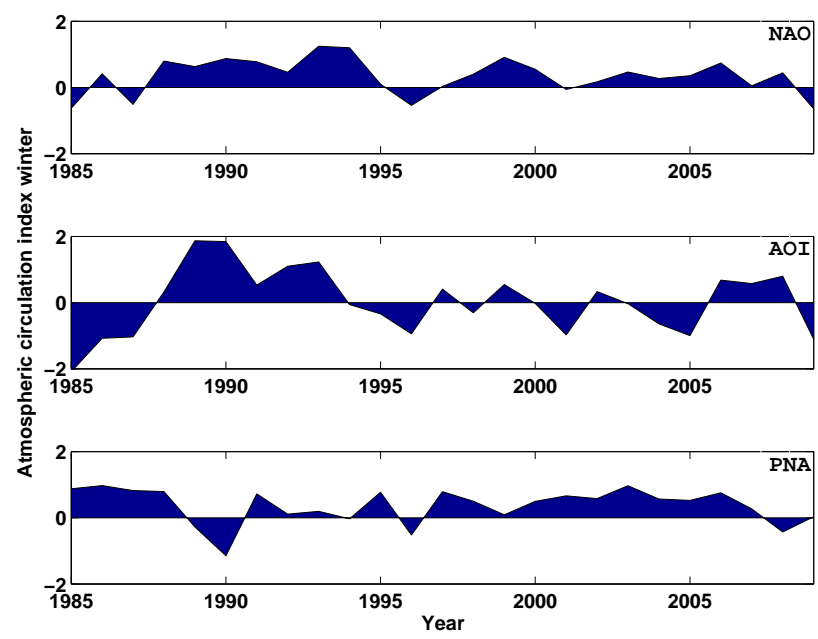

Fig. 6. Annual variation of the atmospheric circulation indices NAO, AOI, and PNA during the winter season.

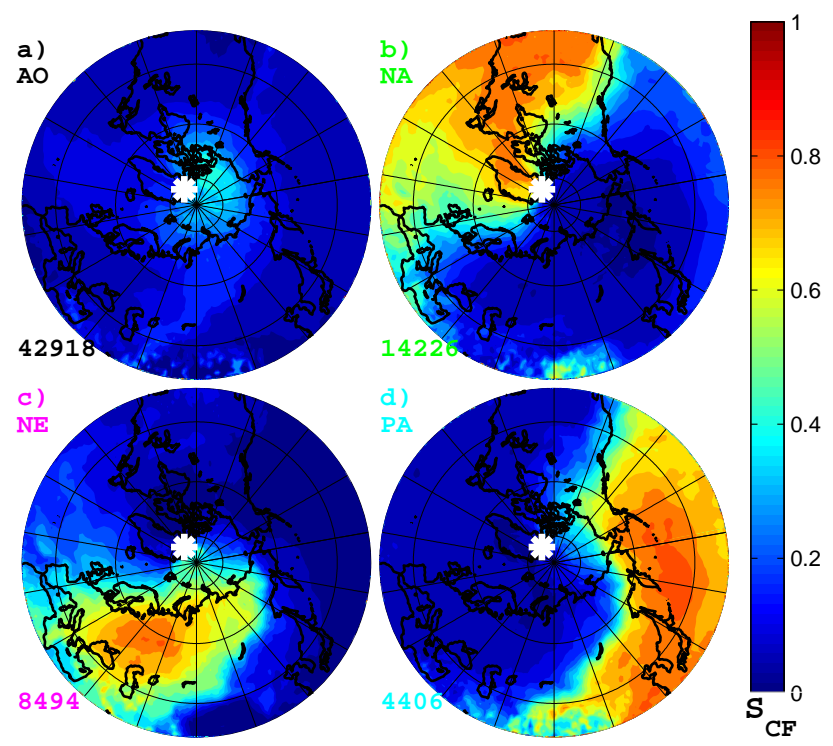

Fig. 7. Annual normalized emission sensitivity $S_{\mathrm{CF}}$ for clusters (a) AO, (b) NA, (c) NE and (d) PA for Alert 1985-2008 (see Eq. 4). The number of cluster members is reported in the bottom left corner of each panel. The location of the Alert station is marked by a white asterisk. AO, Arctic Ocean cluster; NA, North American cluster; NE, Northern Eurasian cluster; and PA, Pacific and SouthEast Asian cluster.

values over Northern Eurasia and especially over its western parts. We subsequently refer to this cluster as the Northern Eurasia (NE) cluster. The 4th and 5th clusters are unique to Zeppelin and essentially form a separation of the NE cluster into a western and eastern part. The 4th cluster shows high $S_{\mathrm{CF}}$ values mainly over western Eurasia (Fig. 9c) and will therefore be referred to as WNE, while the 5th cluster shows high $S_{\mathrm{CF}}$ values over eastern Eurasia and will con-
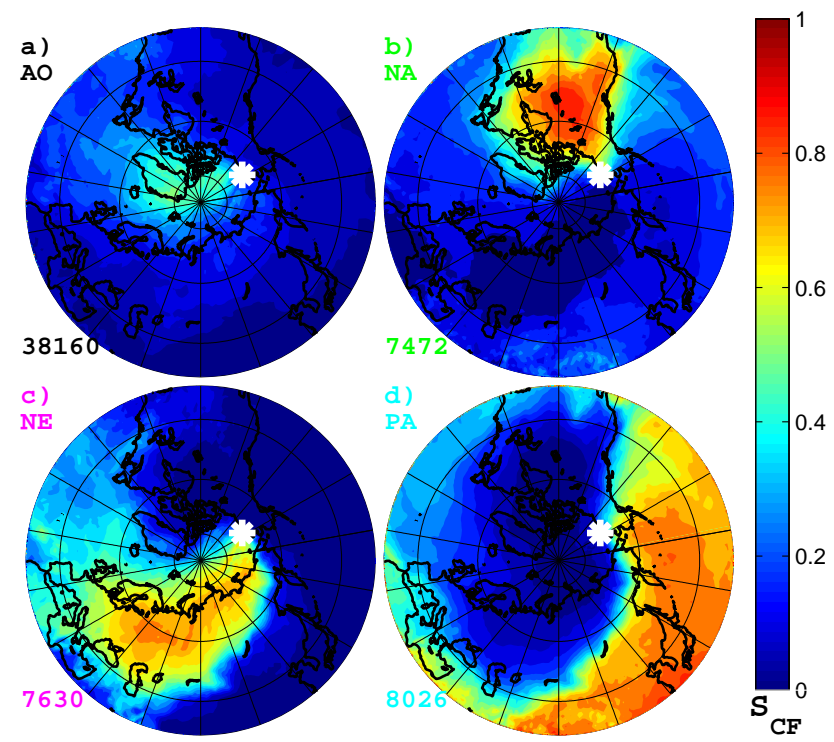

Fig. 8. Same as Fig. 7 for Barrow 1988-2008 (see Eq. 4). The location of the Barrow station is marked by a white asterisk.
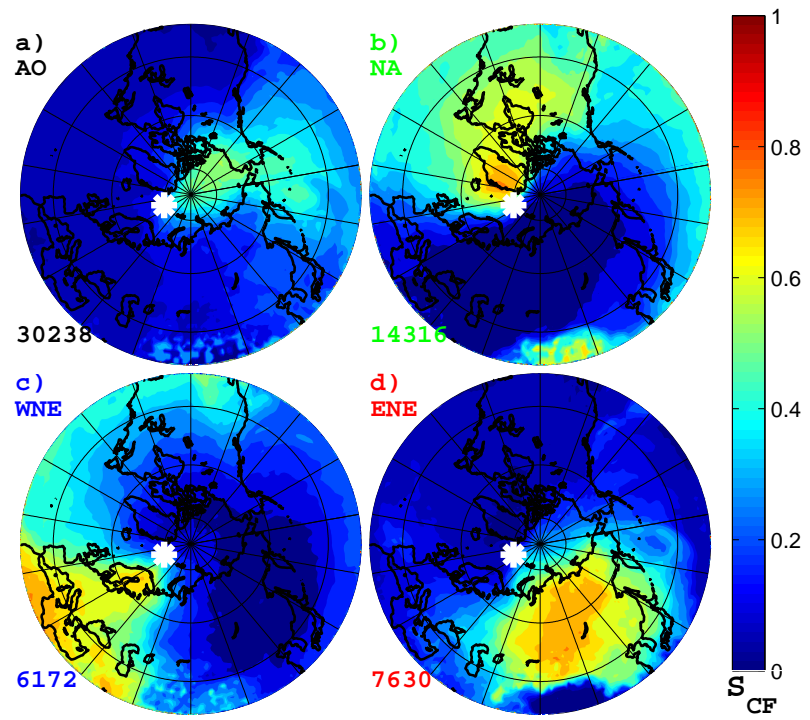

Fig. 9. Same as Fig. 7 but for clusters (a) AO, (b) NA, (c) WNE and (d) ENE for Zeppelin 1990-2009 (see Eq. 4). The location of the Zeppelin station is marked by a white asterisk. AO, Arctic Ocean cluster; NA, North American cluster; WNE, Western Northern Eurasian cluster; and ENE, Eastern Northern Eurasian cluster.

sequently be referred to as ENE (Fig. 9d). Finally, the 6th cluster (Figs. 7d and 8d), only relevant for Alert and Barrow, shows high $S_{\mathrm{CF}}$ values over the North Pacific Ocean and South-East Asia and will thus be referred to as the PacificAsian (PA) cluster.

Alert: at the Alert station, on an annually averaged basis, $\mathrm{AO}$ is the dominant cluster, accounting for over $61 \%$ of 

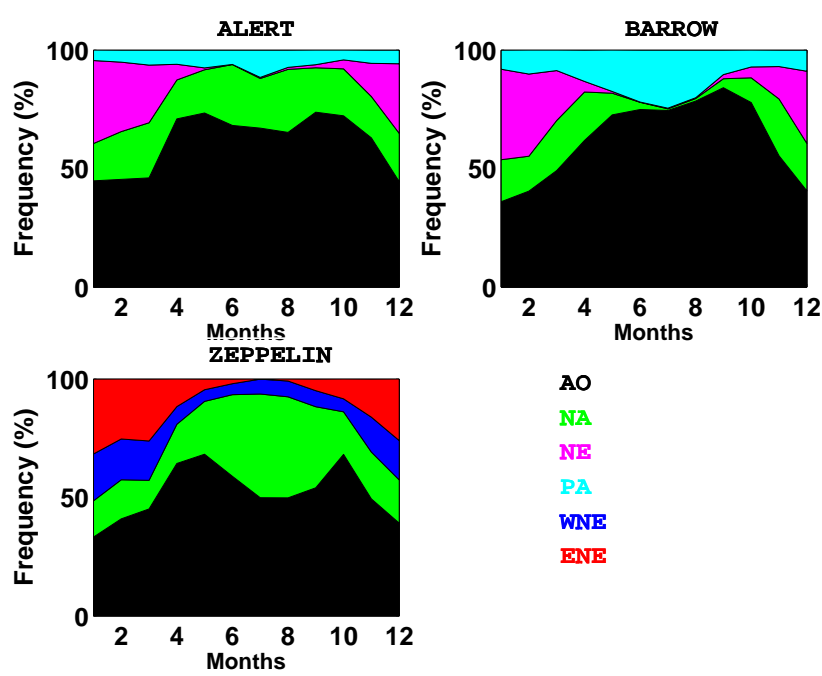

AO

NA

$\mathrm{NE}$

PA

TNE

ENE
Fig. 10. The frequencies of the transport clusters as function of the month of the year for Alert (upper left), Barrow (upper right), and Zeppelin (bottom left).

all cases (Fig. 10). Its frequency is similar from spring to autumn with a maximum of $70 \%$ in autumn. In winter, its frequency is only $45 \%$. The reduction in $\mathrm{AO}$ frequency during winter is compensated by an increased frequency of the $\mathrm{NE}$ cluster which has the largest seasonal variation; $33 \%$ in winter, but less than $1 \%$ in summer. This is consistent with the fact that atmospheric transport from continental source regions into the Arctic is stronger in winter than in summer (Stohl, 2006). The frequencies of the NA and the PA clusters vary less with season, accounting for $19-24 \%$ and 5-8\% of all cases, respectively.

Barrow: at Barrow, the $\mathrm{AO}$ cluster is also most frequent (62\% of all cases), with a maximum frequency in late summer and early autumn (over $80 \%$ ) and a minimum in winter (39\%) (Fig. 10). As for Alert, the NE cluster has the strongest seasonal cycle at Barrow with a maximum frequency of over $34 \%$ during the winter and a minimum of less than $1 \%$ in summer. Also consistent with Alert, the frequencies of the NA and PA clusters are fairly constant throughout the year (13-18\% and 8-13\%) except for summer when the NA frequency decreases significantly (to less than $2 \%$ ) while the PA frequency peaks at $22 \%$.

Zeppelin: at Zeppelin, there is a stronger seasonality of cluster frequencies than for Alert or Barrow (Fig. 10). The AO cluster dominates also at Zeppelin and accounts for $52 \%$ of all cases, with a frequency maximum in spring of $57 \%$ and a wintertime minimum of $38 \%$. NA accounts for $25 \%$ of all cases and is most frequent in summer $(40 \%)$ and least frequent in winter $(17 \%)$. The frequencies of the two Eurasian clusters, WNE and ENE, both peak in winter $(18 \%$ and $28 \%$ respectively) and have a minimum during summertime (6\% and $1 \%)$.
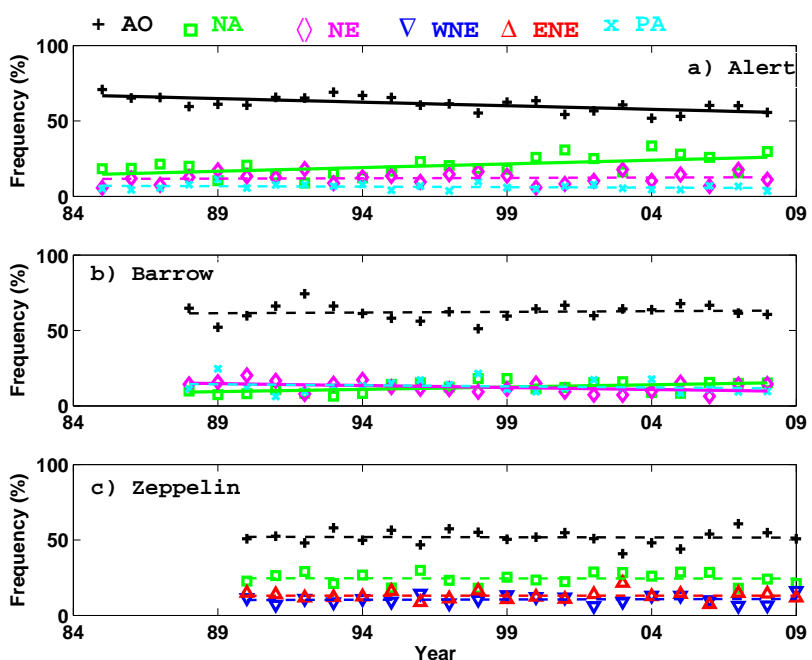

Fig. 11. Annual mean cluster frequency as a function of time at Alert (a), Barrow (b), and Zeppelin (c). The colour codes are indicated at the top. Linear trends are also shown, as solid lines when statistically significant with a minimum confidence of $90 \%$ and as dashed lines when the confidence is lower.

\subsection{Cluster analysis results: trends of transport}

Trends were calculated over the periods for which measurement data were available for the different stations. These periods are slightly different for the three stations.

Alert: the cluster frequencies at Alert show large interannual variability but also strong long-term trends for two of the four clusters. The AO cluster's frequency was $60-70 \%$ at the beginning of the time period but it decreased by about $11 \%$ (or $-0.5 \pm 0.2 \% \mathrm{yr}^{-1}$ ) during the 24 year period (Fig. 11a). The frequency of the NA cluster, on the other hand, shows a similar but opposite trend increasing by $12 \%$ (or $+0.5 \pm 0.3$ $\% \mathrm{yr}^{-1}$ ) over the same time period.

Barrow: the cluster frequencies at Barrow also experience large interannual variability, but their trends are not as clear as for Alert and the rates of change are smaller (Fig. 11b). The NA influence has increased by $6.2 \%( \pm 4.0 \%)$, while the NE influence decreased by $5.2 \%( \pm 4.4 \%)$. The changes for $\mathrm{AO}$ and $\mathrm{PA}$ are not statistically significant.

Zeppelin: at Zeppelin none of the four clusters has a statistically significant trend in frequency because of large interannual variations and the shorter time period considered for this station (Fig. 11c).

The variations in atmospheric transport may, as mentioned above, be related to circulation changes expressed by the NAO index. The strongest correlations between the seasonal NAO index and the frequency of each cluster are found for Alert and Barrow, where the frequency of the NE clusters are correlated with the NAO index, whereas the frequency of the NA clusters are anticorrelated with the NAO index (Table 2). The correlation between the frequency of the transport 
Table 2. Yearly correlation between cluster frequency and NAO index for Alert, Barrow, and Zeppelin. Statistically significant r-values at a $90 \%$ confidence level or higher are shown in bold.

\begin{tabular}{lrrrrrr}
\hline $\begin{array}{l}\text { Station } \\
\text { Corr. Coef./ }\end{array}$ & \multicolumn{2}{c}{ ALERT } & \multicolumn{2}{c}{ BARROW } & \multicolumn{2}{c}{ ZEPPELIN } \\
Cluster & $r$ & p-value & $r$ & p-value & $r$ & p-value \\
\hline AO & 0.23 & 0.28 & 0.16 & 0.48 & -0.34 & 0.14 \\
NA & $-\mathbf{0 . 4 7}$ & $\mathbf{0 . 0 2}$ & $-\mathbf{0 . 6 5}$ & $\mathbf{0 . 0 0}$ & 0.28 & 0.23 \\
NE & $\mathbf{0 . 3 6}$ & $\mathbf{0 . 0 9}$ & $\mathbf{0 . 4 5}$ & $\mathbf{0 . 0 4}$ & - & - \\
WNE & - & - & - & - & 0.07 & 0.78 \\
ENE & - & - & - & - & 0.05 & 0.84 \\
PA & 0.19 & 0.37 & -0.07 & 0.75 & - & - \\
\hline
\end{tabular}

clusters identified for Zeppelin only show significant correlation to the NAO index in the summer (not shown).

\subsection{Cluster means and trends}

Identifying the different clusters representing distinct regimes of atmospheric transport arriving at the three stations was a crucial step in our analysis to investigate the trends of EBC and sulphate. In this section we calculate the annual mean concentrations associated with each of the clusters to reveal differences in measured concentration levels for the various source regions. We then determine the trends in the measured concentrations for each of the clusters in order to relate these trends to emission changes in the respective source regions.

\subsubsection{Equivalent Black Carbon}

The annual geometrical mean EBC concentration differ between the stations where Alert is associated with the highest values, followed by Barrow and thereafter Zeppelin (Fig. 12). At all three stations, the highest measured EBC mean concentrations for all seasons but summer are associated with the Northern Eurasian clusters NE, WNE and ENE (Fig. 12). This result is consistent with earlier studies (Hopper et al., 1994; Polissar et al., 1999, 2001; Sharma et al., 2004, 2006; Hirdman et al., 2010; Gong et al., 2010) which concluded that Northern Eurasia is the main source of EBC for the Arctic near the surface.

Alert: at Alert, the mean EBC concentrations corresponding to the other transport clusters are much lower (by $\sim 45$ $110 \mathrm{ngm}^{-3}$ or $220-375 \%$ ), than the NE EBC concentrations and are not significantly different from each other (Fig. 12a). The annual mean EBC concentrations measured at Alert have a clear negative trend of $-3.8 \% \mathrm{yr}^{-1}$, in accordance with earlier studies (Sharma et al., 2006; Quinn et al., 2007) (Fig. 13a). The largest decreasing EBC concentration trend is seen for cluster NE (Table 3), whereas the weakest decrease is associated with the NA cluster (Table 3) (Fig. 13a).
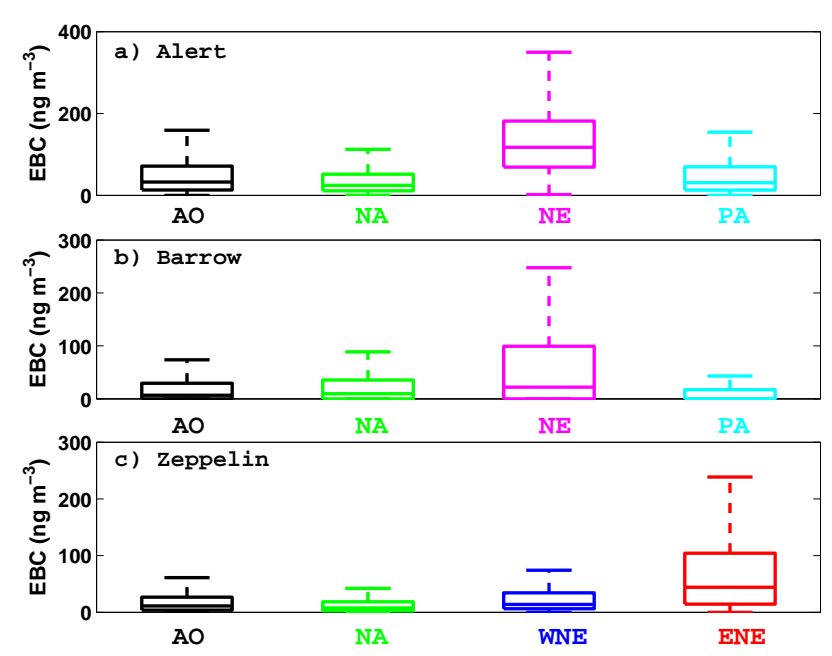

Fig. 12. Box-whisker plots of the EBC concentrations associated with each cluster at Alert (a), Barrow (b), and Zeppelin (c), where the box boundaries mark the 25 th and 75 th percentile of the data and the whiskers includes $99 \%$ of the data.

Barrow: at Barrow, on an annual basis, the NE cluster is associated with the highest and the PA cluster generally is associated with the lowest EBC concentrations (Fig. 12b). In summer, however, the highest EBC concentrations are related to the NA and PA clusters. This result corresponds well with earlier findings indicating that regional sources (including forest fires) are most important for the EBC concentrations in that part of the Arctic in summer (Barrie, 1986; Brock et al., 1989; Stohl, 2006; Hirdman et al., 2010). Due to the change of instrumentation at Barrow in 1998 (as discussed earlier in Sect. 2.1.2), all statistical calculations with this data set are made separately for the two time periods 1988-1997 and 1998-2008 (Fig. 13b). As a result of the shorter continuous time periods and large interannual variations, EBC trends observed in the different clusters as well as for the entire data set are not statistically significant. 
Table 3. Summary of the overall as well as cluster related yearly trends (based on geometric mean conc.) for EBC and sulphate at Alert, Barrow, and Zeppelin. Statistically significant trends at a $90 \%$ confidence level are shown in bold.

\begin{tabular}{|c|c|c|c|c|c|c|}
\hline \multirow{2}{*}{$\begin{array}{l}\text { Station } \\
\text { Species/ } \\
\text { Cluster }\end{array}$} & \multicolumn{2}{|c|}{ ALERT } & \multicolumn{2}{|c|}{ BARROW } & \multicolumn{2}{|c|}{ ZEPPELIN } \\
\hline & $\begin{array}{c}\text { EBC } \\
\left(\mathrm{ngm}^{-3} \mathrm{yr}^{-1}\right) \\
1989-2008\end{array}$ & $\begin{array}{c}\mathrm{SO}_{4} \\
\left(\mathrm{ngm}^{-3} \mathrm{yr}^{-1}\right) \\
1985-2006\end{array}$ & $\begin{array}{c}\mathrm{EBC} \\
\left(\mathrm{ngm}^{-3} \mathrm{yr}^{-1}\right) \\
1988-1997 \\
1998-2008\end{array}$ & $\begin{array}{c}\mathrm{SO}_{4} \\
\left(\mathrm{ngm}^{-3} \mathrm{yr}^{-1}\right) \\
1997-2008\end{array}$ & $\begin{array}{c}\mathrm{EBC} \\
\left(\mathrm{ngm}^{-3} \mathrm{yr}^{-1}\right) \\
2002-2009\end{array}$ & $\begin{array}{c}\mathrm{SO}_{4} \\
\left(\mathrm{ngm}^{-3} \mathrm{yr}^{-1}\right) \\
1990-2008\end{array}$ \\
\hline $\mathrm{AO}$ & $-1.97 \pm 0.35$ & $-13.9 \pm 2.6$ & $\begin{array}{l}-0.55 \pm 1.07 \\
-0.30 \pm 0.85\end{array}$ & $6.9 \pm 14.3$ & $-1.49 \pm 1.02$ & $-1.5 \pm 1.2$ \\
\hline NA & $-1.59 \pm 0.48$ & $-8.9 \pm 5.6$ & $\begin{array}{r}-1.00 \pm 2.63 \\
0.09 \pm 1.38\end{array}$ & $-3.8 \pm 16.1$ & $-1.11 \pm 0.70$ & $0.3 \pm 1.3$ \\
\hline $\mathrm{NE}$ & $-5.45 \pm 1.70$ & $-43.4 \pm 14.3$ & $\begin{array}{l}-0.24 \pm 6.61 \\
-1.20 \pm 3.89\end{array}$ & $-20.3 \pm 40.3$ & - & - \\
\hline WNE & - & - & - & - & $-2.17 \pm 1.64$ & $-4.8 \pm 3.2$ \\
\hline ENE & - & - & - & - & $-0.16 \pm 3.47$ & $-5.6 \pm 2.7$ \\
\hline PA & $-1.73 \pm 0.91$ & $-14.3 \pm 9.1$ & $\begin{array}{l}-0.23 \pm 0.73 \\
-0.28 \pm 0.59\end{array}$ & $2.4 \pm 8.0$ & - & - \\
\hline Total trend (geometric) & $-2.13 \pm 0.42$ & $-14.5 \pm 2.9$ & $\begin{array}{l}-0.85 \pm 1.14 \\
-0.34 \pm 0.87\end{array}$ & $4.4 \pm 13.5$ & $-1.44 \pm 0.8$ & $-1.3 \pm 1.2$ \\
\hline Total trend (arithmetic) & $-3.66 \pm 0.90$ & $-27.3 \pm 5.4$ & $\begin{array}{l}-2.07 \pm 2.31 \\
-0.06 \pm 1.45\end{array}$ & $4.6 \pm 11.8$ & $-4.84 \pm 5.13$ & $-3.4 \pm 1.7$ \\
\hline Total trend (transport) & $0.01 \pm 0.20$ & $-1.4 \pm 1.5$ & $-0.15 \pm 0.12$ & $-1.6 \pm 1.1$ & $-0.23 \pm 0.40$ & $-0.01 \pm 0.49$ \\
\hline
\end{tabular}

Zeppelin: at Zeppelin, the highest annual mean EBC concentrations are associated with the ENE cluster followed by the WNE cluster (Fig. 12c)., while the lowest EBC concentrations occur with cluster NA. However, in spring, cluster WNE has, in some years, the highest EBC mean values due to the influence from the agricultural fires in Eastern Europe in springtime (Stohl et al., 2007; Treffeisen et al., 2007) while the EBC concentrations associated with cluster ENE are more stable. The annual EBC concentrations decrease at a rate of $-9 \% \mathrm{yr}^{-1}\left(-1.44 \pm 0.8 \mathrm{ngm}^{-3} \mathrm{yr}^{-1}\right)$ (Fig. 13c). The decrease is consistent and significant for all clusters but ENE, which shows a statistically significant increase in winter $\left(+9.4 \% \mathrm{yr}^{-1}\right.$ or $\left.4.1 \pm 3.3 \mathrm{ngm}^{-3} \mathrm{yr}^{-1}\right)$ and this increase might be related to emission increases in China.

Comparing these results to previous trend studies, we find that the annual mean EBC concentration measured at Alert (1989-2008) show an even larger decreasing trend than previously presented ( $-72 \%$ against $-54 \%$ during $1989-2006$, Sharma et al., 2006). Also the EBC at Zeppelin (2002-2009) showed a stronger negative trend $\left(-1.44 \pm 0.8 \mathrm{ngm}^{-3} \mathrm{yr}^{-1}\right)$, than the decrease of $-0.95 \mathrm{ngm}^{-3} \mathrm{yr}^{-1}$ reported by Eleftheriadis et al. (2009) for the time period 2001-2007. For the EBC concentrations measured at Barrow, there were no significant trends observed due to the change in instrumentation and the inconsistency between these measurements (see Sect. 2.1.2). Previous studies have merged the two time series into one and derived long-term trends without mentioning how this merging have been performed or quantifying the uncertainties associated with this action (Sharma et al., 2006; Quinn et al., 2007).

\subsubsection{Sulphate aerosol}

In accordance with EBC, the annual geometrical mean sulphate concentration for Alert once again is associated with the highest values, followed by Barrow and Zeppelin (Fig. 15). As for EBC, the highest sulphate concentrations are associated with the Northern Eurasian clusters NE, WNE and ENE for all three stations (Fig. 14), further confirming this area as the major source region for sulphate in Arctic near-surface air (Raatz and Shaw, 1984; Quinn et al., 2007, 2009; Hirdman et al., 2010). There are, however, prominent seasonal differences between the three stations.

Alert: the highest annual mean sulphate values measured at Alert are systematically associated with the NE cluster (Fig. 14a). This holds true for all seasons except for summer when the sulphate concentrations for all clusters are low and similar. For the other three clusters, the interannual variation of sulphate concentrations is large and no systematic difference between the clusters is found. The annual trend in sulphate at Alert is negative for all clusters and for all seasons. Between 1985 and 2006, the sulphate concentrations decreased by $63.9 \%$ (see Fig. 15a). The negative relative trends are similar for the AO, NE and PA clusters, all displaying a decrease of $66-68 \%$ while the NA decrease is less than $53 \%$ (see Table 3).

Barrow: at Barrow, the highest sulphate concentrations are also associated with the NE cluster followed by the NA cluster (Fig. 14b). The lowest concentrations are related to the PA cluster, except in the year of 2006 when it is instead related to the overall highest concentrations. No significant trends were 

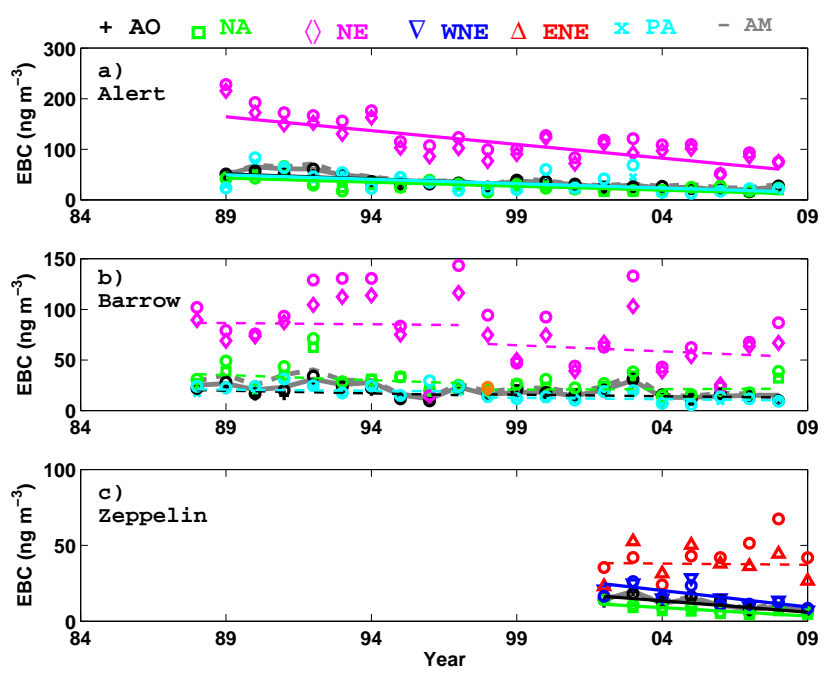

Fig. 13. Annual geometrical mean and median values of the EBC concentrations for all measurements (solid gray and dashed gray respectively) as well as associated to the four different clusters at Alert (a), Barrow (b), and Zeppelin (c). Medians are marked with circles and geometric means with unique symbols according to the legend at the top. Trend lines calculated from the geometrical mean values are shown with solid lines for trends with a statistical significance on the $90 \%$ confidence level, other trends are shown with dashed lines. Due to change in instrumentation at Barrow, this data set was divided in the sub-periods 1988-1997 and 1998-2008 for which linear trends were calculated separately. The mean and median values measured with the old instrument in 1998 are shown in orange.

seen in the measured sulphate at Barrow over the time period of this study, neither for the entire data set nor for any of the clustered subsets (Fig. 15b). This is due mainly to the short time period with available data. The Alert data show that the trends at this station were stronger for the earlier years than for the period for which data are available at Barrow.

Zeppelin: the highest sulphate concentrations at Zeppelin are associated with the ENE clusters, followed by the WNE cluster (Fig. 14c). The smelting industry in Norilsk is situated in the region where the ENE cluster is most sensitive to emissions, again confirming the importance of this source region (Khokhar et al., 2005; Hirdman et al., 2010). The lowest concentrations are associated with the NA cluster. There was a general, statistically significant, decrease of sulphate concentrations at Zeppelin of $21.5 \%$ over the whole time period (see Fig. 15c). This decreasing trend is most pronounced for the WNE cluster $(-52.6 \%)$ and least so for the NA cluster $(-9.7 \%)$ (for more details see Table 3).

The long-term trend of the annual mean sulphate aerosol concentrations measured at the three stations agrees quite well (although somewhat lower) with what has been previously reported for springtime by Quinn et al. (2007). Alert shows a clear decrease of $-64 \%$ (1985-2006) compared with
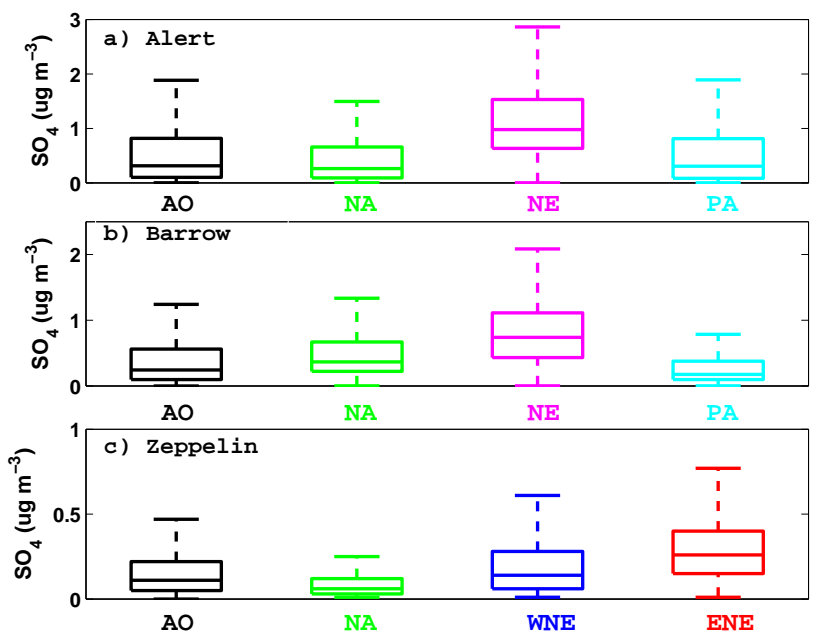

Fig. 14. Box-whisker plots over the sulphate concentration associated to each cluster at Alert (a), Barrow (b), and Zeppelin (c), where the box boundaries are set to mark the 25 th and 75 th percentile of the data whereas the whiskers includes up to $99 \%$ of the data. Outliers outside this have not been plotted in order to emphasis the difference between the different clusters. The horizontal line in each box marks the median value.

$-66-71 \%$ in springtime (1981-2003) as reported by Quinn et al. (2007). The reduction in measured sulphate of $-22 \%$ (1990-2008) at Zeppelin well compares with -27-33\% in spring 1990-2003) reported by Quinn et al. (2007). In agreement with Quinn et al. (2007), we find no significant trends for Barrow.

\subsection{The relative importance of changing transport and changing emissions for the overall trends}

So far, we have investigated the mean EBC and sulphate concentrations and their trends for every cluster individually and this comparison was made using geometric mean concentrations. The following section uses arithmetic mean concentrations to enable a contribution calculation. The contribution of a particular cluster to the total annual mean concentration also depends on its frequency. To quantify the annual contributions of the four clusters, we multiplied the cluster arithmetic mean concentrations with the respective cluster's frequency. The resulting time series includes the effects of both changing transport pathways and changing emissions on the four clusters' contributions to the total concentration. When summing up the contributions from all four clusters, the original measurement time series is obtained. To investigate the effect of changing transport pathways on the cluster contributions alone, we also calculated the contributions when holding the cluster mean concentrations constant over time. For this, we arbitrarily used the cluster-mean concentrations derived from the first three years of the time series. In this case, the sum of the cluster contributions is influenced only 

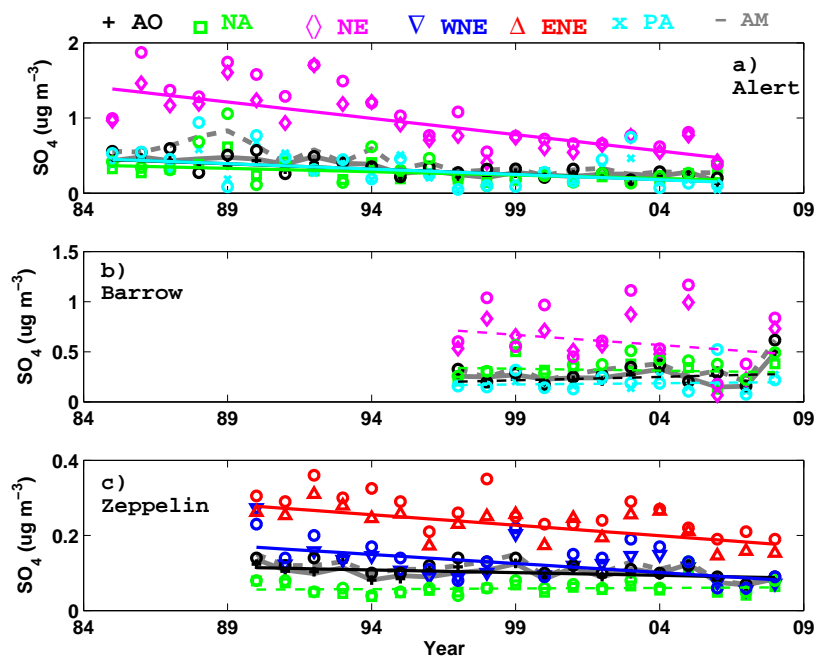

Fig. 15. Annual geometrical means and medians of the sulphate concentrations for all measurements (solid gray and dashed gray respectively) and for the four different clusters at Alert (a), Barrow (b), and Zeppelin (c). Medians are marked with circles and geometric means with unique symbols according to the legend at the top. Trend lines calculated from the geometrical mean values are shown with solid lines for trends with a statistical significance on the $90 \%$ confidence level, other trends are shown with dashed lines.

by changes in cluster frequencies. Comparison of trend estimates with constant and varying cluster-mean concentrations thus allow quantification of the fraction of the total trend that is due to circulation changes. Notice that this fraction is actually a lower estimate because the classification into four clusters cannot fully capture the circulation-related variability. The choice of the first three years of data is arbitrary but the results when using mean values over the whole period were consistent with this approach (not shown).

\subsubsection{Equivalent Black Carbon}

Alert: at Alert, the largest contribution to the measured EBC comes from the AO cluster (see Fig. 16a). This is due to its high frequency, which more than well compensates for the below-average concentrations associated with it. The second largest contributor is the NE cluster followed by clusters NA and PA. The EBC concentration decreased rapidly in the 1990s but it has remained nearly constant since 1998. While the observations for the whole time period display a clear trend $\left(-3.7 \pm 0.9 \mathrm{ngm}^{-3} \mathrm{yr}^{-1}\right)$, no trend at all $\left(0.0 \pm 0.2 \mathrm{ngm}^{-3} \mathrm{yr}^{-1}\right)$ is visible when holding the clustermean concentrations constant. This is explained by the fact that the mean EBC concentrations of clusters $\mathrm{AO}$ and NA, which show the largest and opposing trends in frequency, are very similar (see Fig. 11). This shows that at Alert, changes in the EBC concentrations are driven mainly by emission changes, not by circulation changes, despite the trend of the $\mathrm{NAO}$ indices towards lower values during the period of avail-
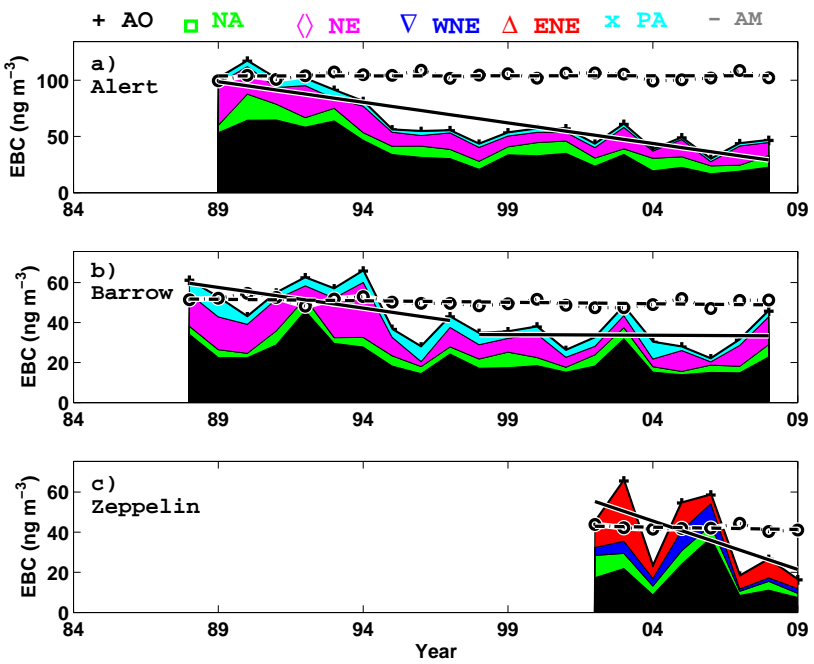

Fig. 16. The annual mean EBC concentrations measured at Alert (a), Barrow (b), and Zeppelin (c) and split into contributions from the four transport clusters. The solid line shows the linear trend through the measured concentrations. The circles show the annual mean EBC concentrations when the cluster-mean concentrations are held constant over time (means over the first three years). This line is influenced only by changes in the frequencies of the four clusters. The dashed line shows the linear trend of these data.

able measurement data, which is consistent with the findings of Gong et al. (2010).

Barrow: at Barrow, the interannual variability of the annual mean EBC concentrations is larger than at Alert and none of the trends is statistically significant at a $90 \%$ confidence level (Fig. 16b). The variability is driven mainly by changing contributions from the dominant $\mathrm{AO}$ cluster. However, in some years (e.g., 1994) cluster NE is the largest contributor. Trend estimates at Barrow are complicated by the break in the measurement record but it appears that the trend since 1998 was very small: $-0.06 \mathrm{ngm}^{-3} \mathrm{yr}^{-1}$. There was a much larger downward trend of $-2.07 \mathrm{ngm}^{-3} \mathrm{yr}^{-1}$ during the first period, however. When holding the cluster mean concentrations constant, there is still a small downward trend of $-0.15 \mathrm{ngm}^{-3} \mathrm{yr}^{-1}$ over the entire time period, which is driven mainly by a decreasing frequency of the EBC-rich NE cluster. This can be well understood by its relationship with the NAO. The circulation-related fraction of the measured trend is relatively small (7.2\%) during the first part of the measurement time series. However, during the second period, the circulation-driven trend is actually $233 \%$ of the observed trend, so that it seems possible that emissions in regions influencing Barrow have slightly (but insignificantly) increased during the second period.

Zeppelin: even though the EBC data record is rather short at Zeppelin (Fig. 16c), mean concentrations have been decreasing during that period and about $4.9 \%$ of that decrease can be explained by circulation changes, the larger 
part is driven by emission reductions. The overall decreasing trend runs counter to a recent $\mathrm{BC}$ emission inventory for the Svalbard area, which reports small but strongly increasing emissions between the year 2000 and 2007, which are mostly driven by increased shipping emissions (Vestreng et al., 2009). Obviously, the EBC concentrations at Zeppelin are still more influenced by emission sources outside the Svalbard area than by the relatively small local emissions. However, further increases in local emissions would eventually also increase local concentrations.

\subsubsection{Sulphate aerosol}

Alert: the cluster contribution to the measured sulphate shows strong similarities with the EBC at Alert, with relatively small interannual variability (Fig. 17a) but a strong and consistent downward trend. While only $5.3 \%$ of the total observed trend can be explained by the trend in the transport, variability of the transport does explain a lot of the year-toyear variation of the measured sulphate, with observed local maxima or minima mostly corresponding to maxima and minima of the time series with fixed cluster concentrations. A strong decrease of the measured sulphate concentrations can be observed especially in the early 1990s, after the breakdown of the former Soviet Union.

Barrow: at Barrow, the total observed change, $+4.6 \pm 11.8 \mathrm{ngm}^{-3} \mathrm{yr}^{-1}$, is insignificant (Fig. 17b). When holding the cluster mean concentrations constant, there is a small downward trend of $-1.6 \pm 1.1 \mathrm{ngm}^{-3} \mathrm{yr}^{-1}$, which is mainly driven by the decreasing frequency of the NE cluster. This is similar to EBC where the circulation-related trend also runs counter to the observed trend, suggesting that emissions may have actually increased over the time period considered. However, the time period is too short to reveal any significant trend.

Zeppelin: at Zeppelin, the overall observed trend is $-3.4 \pm 1.7 \mathrm{ngm}^{-3} \mathrm{yr}^{-1}$, whereas when holding the cluster mean concentrations constant the overall trend is insignificant and small, $-0.01 \pm 0.49 \mathrm{ngm}^{-3} \mathrm{yr}^{-1}$ (Fig. 17c). Only $0.3 \%$ of the decreasing trend can be explained by the changes in the circulation.

\section{Conclusions}

In this paper we have presented trend calculations for equivalent black carbon and sulphate for three Arctic stations, Alert, Barrow, and Zeppelin. We have also investigated which source regions have determined the overall concentrations and their long-term trends. Finally, we have quantified the impact of variations in atmospheric transport on the longterm trends. Listed below are the main findings of this study.

1. There is a general downward trend in the measured EBC concentrations at all stations, with an annual decrease of $-2.1 \pm 0.4 \mathrm{ngm}^{-3} \mathrm{yr}^{-1}$ (for the years 1989-2008) and
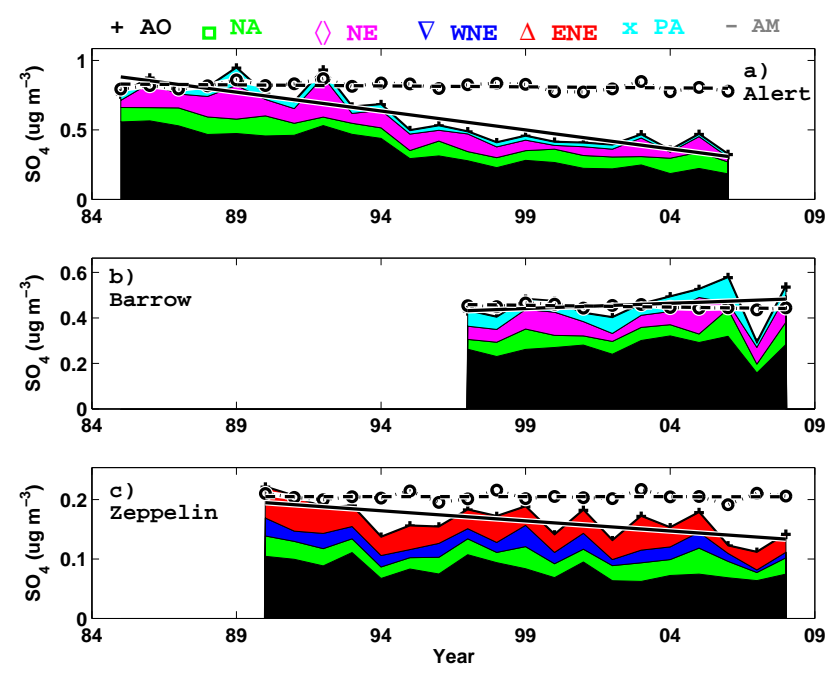

Fig. 17. Same as Fig. 16 but for sulphate.

$-1.4 \pm 0.8 \mathrm{ngm}^{-3} \mathrm{yr}^{-1}(2002-2009)$ at Alert and Zeppelin respectively. The decrease at Barrow is not statistically significant.

2. The measured sulphate concentrations show a decreasing trend at Alert and Zeppelin of $-15 \pm 3 \mathrm{ngm}^{-3}$ (1985-2006) and $-1.3 \pm 1.2 \mathrm{ngm}^{-3}$ (1990-2008) per year respectively, while at Barrow the trend is not detectable.

3. Northern Eurasia (clusters NE, WNE and ENE) is the dominant emission source region for both EBC and sulphate at all Arctic stations.

4. There are indications that the EBC emissions from ENE in wintertime have increased over the last decade, probably reflecting emission increases in China and other East Asian countries. Emissions associated with the other clusters (AO, NA, PA, and WNE) have been stable or decreasing over the time periods in this study, thus driving the overall trend.

5. Transport explains a major part of the interannual variability of EBC and sulphate concentrations at the stations. At the same time, however, only a minor part of the long-term trends in EBC $(0.3-7.2 \%)$ and sulphate $(0.3-5.3 \%)$ can be explained by changes in transport patterns.

6. The interannual variation of the cluster frequency is relatively well correlated to the annual NAO index, which shows a downward trend since most of the measurements started. However, the circulation changes are not large enough to cause substantial long-term trends of EBC and sulphate. 
7. The large interannual variability in the measured EBC and sulphate concentrations at all stations can mask trends over shorter periods, which points out the importance of continuous monitoring in the Arctic over long time periods.

8. The change of instrumentation at Barrow in 1998 severely affects our capability to derive EBC trends for periods overlapping this point in time. While previous studies have reported longer-term trends, based on a comparison of measurements during overlapping period, we have low confidence in longer-term trend estimates at Barrow.

Acknowledgements. We thank ECMWF and met.no for access to the ECMWF archives. We would also like to thank the Global Monitoring Division at NOAA Earth System Research Laboratory, the Atmospheric Science and Technology Directorate at Environment Canada and KLIF Norway for providing data. The Swedish Environmental Protection Agency and the Swedish Research Council have sponsored EBC measurements at Zeppelin. Funding for this study was provided by the Norwegian Research Council through the POLARCAT and SUMSVAL projects.

Edited by: K. Law

\section{References}

Aas, W., Solberg, S., Manø, S., and Yttri, K. E.: Monitoring of long range transported air pollutants, annual report for 2007, Norwegian Institute for Air Research, Kjeller, 2008.

Adam, J. C. and Lettenmaier, D. P.: Application of New Precipitation and Reconstructed Streamflow Products to Streamflow Trend Attribution in Northern Eurasia, J. Climate, 28, 18071828, doi:10.1175/2007JCLI1535.1, 2008.

Ambaum, M. H. P., Hoskins, B. J., and Stephenson, D. B: Arctic Oscillation or North Atlantic Oscillation?, J. Climate, 14, 34953507, 2001.

Arnott, W., Hamasha, K., Moosmuller, H., Sheridan, P., and Ogren, J.: Towards aerosol light-absorption measurements with a 7wavelength aethalometer: Evaluation with a photoacoustic instrument and 3-wavelength nephelometer, Aerosol Sci. Technol., 39, 17-29, 2005.

Ashbaugh, L.: A statistical trajectory technique for determining airpollution source regions, Journal of the Air Pollution Control Association, 33, 1096-1098, 1983.

Ashbaugh, L., Malm, W., and Sadeh, W.: A residence time probability analysis of sulfur concentrations at grand-canyon-nationalpark, Atmos. Environ., 19, 1263-1270, 1985.

Barnston, A. G. and Livezey, R. E.: Classification, seasonality and persistence of low-frequency atmospheric circulation patterns. Mon. Weather Rev., 115, 1083-1126, 1987.

Barrie, L.: Arctic air-pollution - an overview of current knowledge, Atmos. Environ., 20, 643-663, 1986.

Bodhaine, B. A. and Dutton, E. G.: A long-term decrease in Arctic Haze at Barrow, Alaska, Geophys. Res. Lett., 20, 947-950, 1993.

Bond, T., Anderson, T., and Campbell, D.: Calibration and intercomparison of filter-based measurements of visible light absorption by aerosols, Aerosol Sci. Technol., 30, 582-600, 1999.
Bond, T. and Bergstrom, R.: Light absorption by carbonaceous particles: An investigative review, Aerosol Sci. Technol., 40, 27-67, 2006.

Bréon, F.-M., Tanré, D., and Generosso, S.: Aerosol Effect on Cloud Droplet Size Monitored from Satellite, Science, 295, 5556, doi:10.1126/science.1066434, 2002.

Brock, C. A., Radke, L. F., Lyons, J. H., and Hobbs, P. V.: Arctic Hazes in summer over Greenland and the North American Arctic. I: Incidence and Origins, J. Atmos. Chem., 9, 129-148, 1989.

Burkhart, J. F., Bales, R. C., McConnell, J. R., and Hutterli, M. A.: Influence of North Atlantic Oscillation on anthropogenic transport recorded in northwest Greenland ice cores, J. Geophys. Res., 111, D22309, doi:10.1029/2005JD006771, 2006.

Charlson, R. J., Schwartz, S. E., Hales, J. M., Cess, R. D., Coakley, J. A., Hansen, J. E., and Hofmann, D. J.: Climate Forcing by Anthropogenic Aerosols, Science, 255, 423-430, 1992.

Chatterjee, S. and Hadi. A. S.: Influential Observations, High Leverage Points, and Outliers in Linear Regression, Statistical Science, 1, 379-416, 1986.

Delene, D. and Ogren, J.: Variability of aerosol optical properties at four North American surface monitoring sites, J. Atmos. Sci., 59, 1135-1150, 2002.

Dickson, R. R., Osborn, T. J., Hurrell, J. W., Meincke, J., Blindheim, J., Adlandsvik, B., et al.: The Arctic Ocean Response to the North Atlantic Oscillation, J. Climate, 13, 2671-2696, 2000.

Eckhardt, S., Stohl, A., Beirle, S., Spichtinger, N., James, P., Forster, C., Junker, C., Wagner, T., Platt, U., and Jennings, S. G.: The North Atlantic Oscillation controls air pollution transport to the Arctic, Atmos. Chem. Phys., 3, 1769-1778, doi:10.5194/acp3-1769-2003, 2003.

Eleftheriadis, K., Vratolis, S., and Nyeki, S.: Aerosol black carbon in the European Arctic: Measurements at Zeppelin station, Ny-Ålesund, Svalbard from 1998-2007, Geophys. Res. Lett., 36, L02809, doi:10.1029/2008GL035741, 2009.

Engvall, A.-C., Ström, J., Tunved, P., Krejci, R., Schlager, H., and Minikin, A.: The radiative effect of an aged, internally-mixed Arctic aerosol originating from lower-latitude biomass burning, Tellus B, 61, 677-684, 2009.

Flanner, M. G. and Zender, C. S.: Linking snowpack microphysics and albedo evolution, J. Geophys. Res., 111, D12208, doi:10.1029/2005JD006834, 2006.

Flanner, M. G., Zender, C. S., Randerson, J. T., and Rasch, P. J.: Present-day climate forcing and response from black carbon in snow, J. Geophys. Res., 112, D11202, doi:10.1029/2006JD008003, 2007.

Folland C. K., Knight, J., Linderholm, H. W., Fereday, D., Ineson, S., and Hurrell, J. W.: The Summer North Atlantic Oscillation: Past, Present and Future, J. Climate, 22, 1082-1103, 2009.

Forster, C., Stohl, A., and Seibert, P.: Parameterization of convective transport in a lagrangian particle dispersion model and its evaluation, J. Appl. Meteorol. Climatol., 46, 403-422, 2007.

Garrett, T. J., Radke, L. F., and Hobbs, P. V.: Aerosol Effects on Cloud Emissivity and Surface Longwave Heating in the Arctic, J. Atmos. Sci., 59, 769-778, 2002.

Gong, S. L., Zhao, T. L., Sharma, S., Toom-Saunry, D., Lavoué, D., Zhang, X. B., et al.: Identification of trends and interannual variability of sulfate and black carbon in the Canadian High Arctic: 1981-2007, J. Geophys. Res., 115, D07305, doi:10.1029/2009JD012943, 2010. 
Goodall, C. R.: Computation Using the QR Decomposition, Handbook in Statistics, 9, 1993.

Han, Y., Holsen, T., Hopke, P., and Yi, S.: Comparison between back-trajectory based modeling and lagrangian backward dispersion modeling for locating sources of reactive gaseous mercury, Environ. Sci. Technol., 39, 1715-1723, 2005.

Hansen, J. and Nazarenko, L.: Soot climate forcing via snow and ice albedos, P. Natl. Acad. Sci. USA, 101, 423-428, doi:10.1073/pnas.2237157100, 2004.

Helmig, D., Oltmans, S., Carlson, D., Lamarque, J., Jones, A., Labuschagne, C. et al.: A review of surface ozone in the polar regions, Atmos. Environ., 41, 5138-5161, 2007a.

Helmig, D., Oltmans, S., Morse, T., and Dibb, J.: What is causing high ozone at Summit, Greenland?, Atmos. Environ., 41, 50315043, 2007b.

Higgins, R. W., Leetmaa, A., Xue, Y., and Barnston, A.: Dominant factors influencing the seasonal predictability of U.S. precipitation and surface air temperature, J. Climate, 13, 3994-4017, 2000.

Hirdman, D., Aspmo, K., Burkhart J. F., Eckhardt, S., Sodemann, H., and Stohl, A.: Transport of mercury in the Arctic atmosphere: evidence for a spring-time net sink and summer-time source, Geophys. Res. Lett., 36, L12814, doi:10.1029/2009GL038345, 2009.

Hirdman, D., Sodemann, H., Eckhardt, S., Burkhart, J. F., Jefferson, A., Mefford, T., Quinn, P. K., Sharma, S., Ström, J., and Stohl, A.: Source identification of short-lived air pollutants in the Arctic using statistical analysis of measurement data and particle dispersion model output, Atmos. Chem. Phys., 10, 669-693, doi:10.5194/acp-10-669-2010, 2010.

Hole, L. R., Christensen, J. H., Ruoho-Airola, T., Tørseth, K., Ginzburg, V., and Glowacki, P.: Past and future trends in concentrations of sulphur and nitrogen compounds in the Arctic, Atmos. Environ., 43, 928-939, 2009.

Hopper, J. F., Worthy, E. J., Barrie, L. A., and Trivell, N. B. A.: Atmospheric observations of aerosol black carbon, carbon dioxide, and methane in the high Arctic, Atmos. Environ., 18, 3047-3054, 1994.

Hurrell, J. W.: Transient Eddy Forcing of the Rotational Flow during Northern Winter, J. Atmos. Sci., 52, 2286-2301, 1995.

Hurrell J. W. and Deser, C.: North Atlantic climate variability: The role of the North Atlantic Oscillation, J. Marine Syst., 79, 231244,2010

Iziomon, M. G., Lohmann, U., and Quinn, P. K.: Summertime pollution events in the Arctic and potential implications, J. Geophys. Res., 111, D12206, doi:10.1029/2005JD006223, 2006.

Kalkstein, L. S., Tan, G., and Skindlov, J. A.: An evaluation of three clustering procedures for use in synoptic climatological classification, J. Clim. Appl. Meteorol., 26, 717-730, 1987.

Kaufman, L. and Rousseeuw, P. J.: Finding Groups in Data: An Introduction to Cluster Analysis. Hoboken, NJ: John Wiley \& Sons, Inc., 1990.

Khokhar, M. F., Frankenberg, C., Van Roozendael, M., Beirle, S., Kühl, S., Richter, A., et al.: Satellite observations of atmospheric SO2 from volcanic eruptions during the time-period of 19962002, Adv. Space Res., 36, 879-887, 2005.

Koch, D. and Hansen, J.: Distant origins of arctic black carbon: A Goddard Institute for Space Studies modelE experiment, J. Geophys. Res., 110, D18104, doi:10.1029/2004JD005296, 2005.
Krecl, P., Strom, J., and Johansson, C.: Carbon content of atmospheric aerosols in a residential area during the wood combustion season in Sweden, Atmos. Environ., 41, 6974-6985, 2007.

Liu, X., Penner, J. E., and Herzog, M.: Global modeling of aerosol dynamics: Model description, evaluation, and interactions between sulfate and nonsulfate aerosols, J. Geophys. Res., 110, D18206, doi:10.1029/2004JD005674, 2005.

McConnell, J., Edwards, R., Kok, G., Flanner, M., Zender, C., Saltzman, E., et al.: 20th-century industrial black carbon emissions altered Arctic climate forcing, Science, 317, 1381-1384, 2007.

New, M., Todd, M., Hulme, M., and Jones, P.: Precipitation Measurements and Trends in the Twentieth Century, Int. J. Climatol., 21, 1899-1922, doi:10.1002/joc.680, 2001.

Paris, J.-D., Stohl, A., Ciais, P., Nédélec, P., Belan, B. D., Arshinov, M. Yu., and Ramonet, M.: Source-receptor relationships for airborne measurements of $\mathrm{CO}_{2}, \mathrm{CO}$ and $\mathrm{O}_{3}$ above Siberia: a cluster-based approach, Atmos. Chem. Phys., 10, 1671-1687, doi:10.5194/acp-10-1671-2010, 2010.

Park, R. J., Jacob, D. J., Palmer, P. I., Clarke, A. D., Weber, R. J., Zondlo, M. A., et al.: Export efficiency of black carbon aerosol in continental outflow: Global implications, J. Goephys. Res., 110, D11205, doi:10.1029/2004JD005432, 2005.

Polissar, A., Hopke, P., Paatero, P., Kaufmann, Y., Hall, D., Bodhaine, B., et al.: The aerosol at Barrow, Alaska: Long-term trends and source locations, Atmos. Environ., 33, 2441-2458, 1999.

Polissar, A., Hopke, P., and Harris, J.: Source regions for atmospheric aerosol measured at Barrow, Alaska, Environ. Sci. Technol., 35, 4214-4226, 2001.

Quinn, P. K., Coffman, D. J., Kapustin, V. N., Bates, T. S., and Covert, D. S.: Aerosol optical properties in the marine boundary layer during ACE 1 and the underlying chemical and physical aerosol properties, J. Geophys. Res., 103, 16547-16563, 1998.

Quinn, P., Shaw, G., Andrews, E., Dutton, E., Ruoho-Airola, T., and Gong, S.: Arctic haze: Current trends and knowledge gaps, Tellus B, 59, 99-114, 2007.

Quinn, P. K., Bates, T. S., Baum, E., Doubleday, N., Fiore, A. M., Flanner, M., Fridlind, A., Garrett, T. J., Koch, D., Menon, S., Shindell, D., Stohl, A., and Warren, S. G.: Short-lived pollutants in the Arctic: their climate impact and possible mitigation strategies, Atmos. Chem. Phys., 8, 1723-1735, doi:10.5194/acp8-1723-2008, 2008

Quinn, P. K., Bates, T. S., Schulz, K., and Shaw, G. E.: Decadal trends in aerosol chemical composition at Barrow, Alaska: 19762008, Atmos. Chem. Phys., 9, 8883-8888, doi:10.5194/acp9-8883-2009, 2009.

Raatz, W. E. and Shaw, G. E.: Long-Range Tropospheric transport of pollution Aerosols into the Alaskan Arctic, J. Clim. Appl. Meteorol., 23, 1052-1064, 1984.

Seber, G. A. F.: Multivariate Observations. Hoboken, NJ: John Wiley \& Sons, Inc., 1984.

Seibert, P. and Frank, A.: Source-receptor matrix calculation with a Lagrangian particle dispersion model in backward mode, Atmos. Chem. Phys., 4, 51-63, doi:10.5194/acp-4-51-2004, 2004.

Sharma, S., Lavoue, D., Cachier, H., Barrie, L., and Gong, S.: Long-term trends of the black carbon concentrations in the Canadian Arctic, J. Geophys. Res., 109, D15203, doi:10.1029/2003JD004331, 2004. 
Sharma, S., Andrews, E., Barrie, L., Ogren, J., and Lavoue, D.: Variations and sources of the equivalent black carbon in the high Arctic revealed by long-term observations at Alert and Barrow: 1989-2003, J. Geophys. Res., 111, D14208, doi:10.1029/2005JD006581, 2006.

Sirois, A. and Barrie, L.: Arctic lower tropospheric aerosol trends and composition at alert, Canada: 1980-1995, J. Geophys. Res., 104, 11599-11618, 1999.

Spath, H.: Cluster Dissection and Analysis: Theory, FORTRAN Programs, Examples, translated by: Goldschmidt, J., New York: Halsted Press, 1985.

Stohl, A.: Computation, accuracy and applications of trajectories a review and bibliography, Atmos. Environ., 32, 947-966, 1998.

Stohl, A., Eckhardt, S., Forster, C., James, P., Spichtinger, N., and Seibert P.: A replacement for single back trajectory calculations in the interpretation of atmospheric trace substance measurements, Atmos. Environ., 36, 4635-4648, 2002.

Stohl, A., Forster, C., Frank, A., Seibert, P., and Wotawa, G.: Technical note: The Lagrangian particle dispersion model FLEXPART version 6.2, Atmos. Chem. Phys., 5, 2461-2474, doi:10.5194/acp-5-2461-2005, 2005.

Stohl, A.: Characteristics of atmospheric transport into the Arctic troposphere, J. Geophys. Res., 111, D11306, doi:10.1029/2005JD006888, 2006.

Stohl, A., Andrews, E., Burkhart, J., Forster, C., Herber, A., Hoch, S., et al.: Pan-arctic enhancements of light absorbing aerosol concentrations due to North American boreal forest fires during summer 2004, J. Geophys. Res., 111, D22214, doi:10.1029/2006JD007216, 2006.

Stohl, A., Berg, T., Burkhart, J. F., Fjǽraa, A. M., Forster, C., Herber, A., Hov, Ø., Lunder, C., McMillan, W. W., Oltmans, S., Shiobara, M., Simpson, D., Solberg, S., Stebel, K., Strm, J., Trseth, K., Treffeisen, R., Virkkunen, K., and Yttri, K. E.: Arctic smoke - record high air pollution levels in the European Arctic due to agricultural fires in Eastern Europe in spring 2006, Atmos. Chem. Phys., 7, 511-534, doi:10.5194/acp-7-511-2007, 2007.
Sukhinin, A. I., French, N. H. F., Kasischke, E. S., Hewson, J. H., Soja, A. J., Csiszar, I. A., et al.: AVHRR-based mapping of fires in Russia: New products for fire management and carbon cycle studies, Remote Sens. Environ., 93, 546-564, 2004.

Tomasi, C., Vitale, V., Lupi, A., Di Carmine, C., Campanelli, M., Herber, A., et. al.: Aerosol in polar regions: A historical overview based in optical depth and in situ observations, J. Geophys. Res., 112, D16205, doi:10.1029/2007JD008432, 2007.

Treffeisen, R., Tunved, P., Ström, J., Herber, A., Bareiss, J., Helbig, A., Stone, R. S., Hoyningen-Huene, W., Krejci, R., Stohl, A., and Neuber, R.: Arctic smoke - aerosol characteristics during a record smoke event in the European Arctic and its radiative impact, Atmos. Chem. Phys., 7, 3035-3053, doi:10.5194/acp-73035-2007, 2007.

Uppala, S., Kallberg, P., Simmons, A., Andrae, U., Bechtold, V., et al.: The ERA-40 re-analysis, Q. J. Roy. Meteor. Soc, 131, 29613012, 2005.

Vestreng, V., Kallenborn, R., and Økstad, E.: Climate influencing emissions, scenarios and mitigation options at Svalbard, Rapport from the Climate and Pollution Agency in Norway (KLIF), TA2552, 2009.

Warneke, C., Bahreini, R., Brioude, J., Brock, C.A., de Gouw, J. A., Fahey, D. W., et al.: Biomass burning in Siberia and Kazakhstan as an important source for haze over Alaskan Arctic in April 2008, Geophys. Res. Lett., 36, L02813, doi:10.1029/2008GL036194, 2009.

Warneke, C., Froyd, K. D., Brioude, J., Bahreini, R., Brock, C. A., Cozic, J., et al.: An important contribution to springtime Arctic aerosol from biomass burning in Russia, Geophys. Res. Lett., 37, L01801, doi:10.1029/2009GL041816, 2010.

Weingartner, E., Saathoff, H., Schnaiter, M., Streit, N., Bitnar, B., and Baltensperger, U.: Absorption of light by soot particles: Determination of the absorption coefficient by means of aethalometers, J. Aerosol Sci , 34, 1445-1463, 2003.

White, P. W.: ECMWF, IFS Documentation, in, ECMWF, Reading, 2002. 